Article

\title{
From Disposal to Reuse: Production of Sustainable Fatty Acid Alkyl Esters Derived from Residual Oil Using a Biphasic Magnetic Catalyst
}

\author{
Adriano Lima da Silva ${ }^{1, *(1)}$, Carlos Bruno Barreto Luna ${ }^{1}$ (), Ana Flávia Félix de Farias ${ }^{1}$ (D), \\ Suelen Alves Silva Lucena de Medeiros ${ }^{2}\left(\mathbb{D}\right.$, Simoni Margareti Plentz Meneghetti ${ }^{3}$, \\ Alisson Mendes Rodrigues ${ }^{1,4}\left(\mathbb{D}\right.$ and Ana Cristina Figueiredo de Melo Costa ${ }^{1,4}$ \\ 1 Programa de Pós-Graduação em Ciência e Engenharia de Materiais (PPG-CEMat), \\ Universidade Federal de Campina Grande, Av. Aprígio Veloso-882, \\ Bodocongó, Campina Grande 58429-900, PB, Brazil; brunobarretodemaufcg@hotmail.com (C.B.B.L.); \\ anafffr@hotmail.com (A.F.F.d.F.); alisson_mendes@ymail.com (A.M.R.); \\ ana.costa@ufcg.edu.br (A.C.F.d.M.C.) \\ 2 Núcleo de Pesquisa e Extensão, Laboratório de Combustíveis e Materiais, Universidade Federal da Paraíba, \\ João Pessoa 58051-900, PB, Brazil; suelen.als@gmail.com \\ 3 Grupo de Catálise e Reatividade Química (GCAR), Instituto de Química e Biotecnologia, \\ Universidade Federal de Alagoas, Maceió 57072-970, AL, Brazil; simoni.plentz@gmail.com \\ 4 Unidade Acadêmica de Engenharia de Materiais, Centro de Ciências e \\ Tecnologia, Universidade Federal de Campina Grande, Av. Aprígio Veloso-882, Bodocongó, \\ Campina Grande 58429-900, PB, Brazil \\ * Correspondence: adrianolimadasilva@hotmail.com
}

Received: 1 October 2020; Accepted: 11 November 2020; Published: 4 December 2020

\begin{abstract}
The development of technologies to promote residual oil reuse has been encouraged, aiming to reduce the environmental impact and promote sustainability. In this study, a biphasic magnetic catalyst with composition equal to $\mathrm{ZnO}-\mathrm{Ni}_{0.5} \mathrm{Zn}_{0.5} \mathrm{Fe}_{2} \mathrm{O}_{4}$ was synthesized and applied to the fatty acid alkyl ester (FAAE) production from residual oil. The $\mathrm{ZnO}-\mathrm{Ni}_{0.5} \mathrm{Zn}_{0.5} \mathrm{Fe}_{2} \mathrm{O}_{4}$ catalyst was synthesized by combustion reaction and characterized by X-ray diffraction (XRD), textural analysis, Fourier transform infrared spectroscopy (FTIR), Raman spectroscopy, thermogravimetry, particle size distribution, scanning electron microscopy, magnetic measurements, quantification of acidic sites by TPD-NH${ }_{3}$, and catalytic tests. The efficiency of catalyst synthesis was evaluated by XRD, FTIR, and Raman spectroscopy experiments. Granulometric analysis and SEM images confirmed the presence of the agglomerates and particles with a wide size range. The catalyst presented soft magnetic behavior, with high saturation magnetization. Additionally, the catalytic activity of the $\mathrm{ZnO}-\mathrm{Ni}_{0.5} \mathrm{Zn}_{0.5} \mathrm{Fe}_{2} \mathrm{O}_{4}$ system showed an average conversion of $73 \%$ for the methyl route. The results indicate that the reuse of residual oil is feasible for FAAE production, contributing to sustainable fuel development. Moreover, it allows the reintroduction of waste oil into the biodiesel production chain, reducing cost after process optimization.
\end{abstract}

Keywords: residual oil; reuse; biodiesel; magnetic catalyst; sustainability

\section{Introduction}

There has been growing concern regarding environmental issues in recent years due to the accumulation and disposal of postconsumer residues [1,2]. In this scenario, residual cooking oil has attracted attention since when it is improperly disposed of, it can negatively impact the environment [3]. Residual cooking oil is highly polluting and causes water and soil contamination since 
it presents low solubility, low density, and difficulty in degrading through the biological process [4]. Moreover, the dumping of residual oils in sinks and drains can obstruct the networks and increase sewage treatments [5]. Thus, both economic and environmental aspects are strong justifications to promote the reuse of residue oils.

The reusing of residue oils appears to be an alternative solution for sustainable and economic development [6]. The problems resulting from environmental pollution generated by residue oils have led the scientific community to reflect on possible alternatives to solving the problem $[7,8]$. Biodiesel production is an alternative method to reuse residue oils from homes and food industries [9]. As a consequence, there is a contribution to reducing the overall cost of manufacturing and, at the same time, adding value to a post-consumer material $[10,11]$. Generally, biodiesel is produced through transesterification and/or esterification due to the greater availability of triglyceride-rich raw materials [12]. Transesterification and esterification processes are essential to produce the cleanest and most environmentally safe biodiesel [13], using raw materials rich in free fatty acids present in residues and byproducts, such as crude oils and oils used in frying [14,15]. However, such a process is challenging due to undesirable components, mostly free fatty acids [16]. To get around this problem, the use of magnetic catalysts for the transesterification and esterification of oils has gained prominence for biodiesel production, with good conversion yield $[17,18]$. The catalyst plays an essential role in accelerating biodiesel production, minimizing production costs [19].

Heterogeneous catalysis has been highlighted because a solid catalyst is used in this process, which does not mix with the other reagents, facilitating the reaction medium [20]. In this context, magnetic ferrites have stood out as advanced materials for the production of catalysts due to the simplicity of synthesis and good chemical and physical properties that guarantee good performance during the reaction. Moreover, they present the magnetic characteristics that favor the catalyst's magnetic separation [21-23].

Several studies [24-27] on biodiesel production using magnetic catalysts have been carried out. Recently, Pontes et al. [28] developed the magnetic compound $\gamma-\mathrm{Fe}_{2} \mathrm{O}_{3} / \mathrm{Ba}_{3} \mathrm{Co}_{2} \mathrm{Fe}_{24} \mathrm{O}_{41}$ by combustion reaction and, subsequently, tested it as a heterogeneous catalyst in the production of biodiesel from the reactions of methyl esterification of residual soy oil and transesterification of refined oil. In general, the $\gamma-\mathrm{Fe}_{2} \mathrm{O}_{3} / \mathrm{Ba}_{3} \mathrm{Co}_{2} \mathrm{Fe}_{24} \mathrm{O}_{41}$ system was catalytically active, with a conversion of $46.58 \%$ by transesterification and $31.06 \%$ by TES reaction (a combination of esterification and transesterification reactions).

Ali et al. [29] investigated the performance of the $\mathrm{CuFe}_{2} \mathrm{O}_{4}$ magnetic system as a heterogeneous catalyst, aiming at biodiesel's efficient and sustainable production through the process of transesterification of residual frying oil. The catalyst was synthesized by two routes: coprecipitation (CS1) and the combination of hydrothermal coprecipitation (CS2). Hydrothermal coprecipitation increased the catalytic activity of the CS2 system when compared to the CS1 route, which is synthesized only by coprecipitation. The use of $3 \mathrm{wt} \%$ of the catalyst achieved a yield of $90.24 \%$ of biodiesel using the CS2 route. The catalyst produced by the CS2 route was easily recoverable and reusable, and its activity was very stable for five reuses. In general, the $\mathrm{CuFe}_{2} \mathrm{O}_{4}$ magnetic system is a promising heterogeneous catalyst for the production of biodiesel.

The production of magnetic catalysts can contribute to sustainable development since these catalysts can be applied to produce biodiesel from waste oils. Therefore, there is a contribution to solving part of the problem of the inadequate destination of oil residues. The research on the reuse of oil residues for biodiesel production, in the vast majority, uses heterogeneous magnetic catalysts with broad technological potential. However, few studies in the literature explore biphasic magnetic catalysts, namely, $\mathrm{ZnO}-\mathrm{Ni}_{0.5} \mathrm{Zn}_{0.5} \mathrm{Fe}_{2} \mathrm{O}_{4}$, for biodiesel production, thus configuring a relevant point be explored.

Therefore, this work aims to develop a biphasic magnetic catalyst with a composition equal to $\mathrm{ZnO}-\mathrm{Ni}_{0.5} \mathrm{Zn}_{0.5} \mathrm{Fe}_{2} \mathrm{O}_{4}$, aiming to evaluate its technological potential for FAAE production frying oil residue, allowing the use of waste oil into the biodiesel production chain after process optimization. 


\section{Materials and Methods}

\subsection{Materials}

In this research, the $\mathrm{Ni}_{0.5} \mathrm{Zn}_{0.5} \mathrm{Fe}_{2} \mathrm{O}_{4}$ magnetic catalyst was synthesized via a combustion reaction from the following chemical reagents: nickel nitrate hexahydrate $\left(\mathrm{Ni}\left(\mathrm{NO}_{3}\right)_{2} 6 \mathrm{H}_{2} \mathrm{O}\right)$, hexahydrate zinc nitrate $\left(\mathrm{Zn}\left(\mathrm{NO}_{3}\right)_{2} \cdot 6 \mathrm{H}_{2} \mathrm{O}\right)$, iron (III) nitrate nonahydrate $\left(\mathrm{Fe}\left(\mathrm{NO}_{3}\right)_{3} \cdot 9 \mathrm{H}_{2} \mathrm{O}\right)$, and urea. All chemical reagents used were purchased from the Dinâmica (Brazil), with purities between $98 \%$ and $99 \%$ [30]. The catalyst's performance was evaluated on its ability to convert frying oil residual into FAAE via simultaneous transesterification and esterification reactions (TES reactions). The residual soybean oil used, originating from fried pasta, with temperatures close to $180^{\circ} \mathrm{C}$ and an average usage time of $3 \mathrm{~h}$, was collected from pastry shops in Campina Grande, located in Paraíba state, Brazil. The oil was filtered using white strip filter paper. The physicochemical parameters of the residual oil were accomplished in agreement with the AOCS Cd 3d-63 standard, and the result showed a value of 14.8 $\pm 0.005 \mathrm{mg}$ of $\mathrm{KOH} / \mathrm{g}$ of the sample, methyl alcohol $\left(\mathrm{CH}_{3} \mathrm{OH}\right.$ )—purity $99.8 \%$ (Dinâmica), and ethyl alcohol $\left(\mathrm{CH}_{3} \mathrm{CH}_{2} \mathrm{OH}\right)$ - purity $99.5 \%$ (Dinâmica) [30].

\subsection{Methods}

\subsubsection{Catalyst Synthesis}

The combustion reactions were accomplished in a pilot plant built in agreement with the patent BR 102012 002181-3 [30,31]. The pilot plant comprised a stainless-steel container connected to a conical reactor with a $200 \mathrm{~g} / \mathrm{batch}$ capacity. The system reaches a maximum temperature equal to $350^{\circ} \mathrm{C}$ after $60 \mathrm{~min}$.

Before the synthesis of the $\mathrm{ZnO}-\mathrm{Ni}_{0.5} \mathrm{Zn}_{0.5} \mathrm{Fe}_{2} \mathrm{O}_{4}$ magnetic catalyst, the initial composition of the precursor solution was calculated based on the total valence of oxidizing agents and reducing reagents using propellant and explosive chemistry concepts. The autoignition procedure (combustion) was performed in the stoichiometric mixture of metallic nitrates and urea allocated in a stainless-steel container in a conical reactor, with a production capacity of $200 \mathrm{~g} / \mathrm{batch}$ [32].

\subsubsection{Catalyst Heat Treatment}

The catalyst obtained from the combustion reaction in polyphasic form was subjected to a thermal treatment at different temperatures $\left(650,700\right.$, and $\left.800{ }^{\circ} \mathrm{C}\right)$, with a heating rate of $30^{\circ} \mathrm{C} / \mathrm{min}$ and $5 \mathrm{~min}$ of a burning level using an EDG 3000 oven, to evaluate the evolution of crystalline phases of the $\mathrm{ZnO}-\mathrm{Ni}_{0.5} \mathrm{Zn}_{0.5} \mathrm{Fe}_{2} \mathrm{O}_{4}-\mathrm{Fe}_{2} \mathrm{O}_{3}$ system [30].

\subsubsection{Catalytic Test}

The performance of the $\mathrm{ZnO}-\mathrm{Ni}_{0.5} \mathrm{Zn}_{0.5} \mathrm{Fe}_{2} \mathrm{O}_{4}-\mathrm{Fe}_{2} \mathrm{O}_{3}$ magnetic catalyst was evaluated in the synthesis of FAAEs from residual oil via the TES reaction. Before synthesis, the residual oil was filtered (filter paper $15.00 \pm 0.15 \mathrm{~cm}$ ) to remove the suspended particulate matter. The catalytic tests were conducted in duplicates using a pressurized stainless-steel reactor equipped with a pressure gauge, a thermocouple inlet duct, and a borosilicate glass $(80 \mathrm{~mL})$. The experiment conditions were $30 \mathrm{~g}$ oil mass, time $1 \mathrm{~h}$, and an alcohol/oil ratio of 15:1. The heating and agitation of the system were carried out with the aid of an IKA C-MAG HS 7 plate model, external electrical resistance, and a magnetic bar of approximately $2.5 \mathrm{~cm}$. After the reactions, the catalytic tests' products were centrifuged to separate the catalyst, purified, and dried in an oven at $110{ }^{\circ} \mathrm{C}$ for $20 \mathrm{~min}$, with manual stirring at 5-min intervals [30].

\subsubsection{Characterization of the Catalyst}

The $\mathrm{ZnO}-\mathrm{Ni}_{0.5} \mathrm{Zn}_{0.5} \mathrm{Fe}_{2} \mathrm{O}_{4}$ magnetic catalyst synthesized was characterized by $\mathrm{X}$-ray diffraction (XRD) using a BRUKER X-ray diffractometer (model D2 PHASER, $\mathrm{Cu}-\mathrm{K} \alpha$ radiation), operating at 
$30 \mathrm{kV}$ and $10 \mathrm{~mA}$. The angular step and counting time used were $0.016^{\circ}$ and $44 \mathrm{~min}$, respectively [33]. The crystallite size was calculated with the aid of the Scherrer equation $[30,34]$ and from the peak of the most intense basal reflection, see Equation (1).

$$
D=\frac{K \lambda}{\beta \cos \theta}
$$

where $\theta$ is the wavelength of the $\mathrm{X}$-ray beam, $\beta$ is full width at half maximum (FWHM), $\mathrm{h}$ is the Bragg scattering angle, and $\mathrm{K}(=0.89)$ is the shape factor.

The identification of the main crystalline phases was made with the DiffracPlus Suite Eva software and Joint Committee on Powder Diffraction Standards (JCPDS). The quantification of each main crystalline phase was carried out by Rietveld refinement [30,35] with the aid of DIFFRACplus TOPAS Version 3.0 (Bruker AXS). The residual error of the Rietveld refinement was calculated from Equation (2). On Equation (2), $I_{O b s}$ and $I_{C a l c}$ are the observed and calculated intensities for each step, respectively. The $W_{i}$ parameter is calculated from the equation $W_{i}=1 / I_{O b s}$.

$$
S y=\sum_{i} W_{i}\left(I_{O b s}-I_{C a l c}\right)^{2}
$$

The catalyst surface was characterized using the nitrogen gas adsorption and desorption technique. All experiments were carried out in Quantachorme model NOVA 3200 equipment. The surface area and pore diameter were calculated using the Brunauer, Emmett, and Teller (BET) and Brunauer, Joyner, and Halenda (BJH) methods, respectively [30].

The morphological aspects of the catalyst sample were acquired by scanning electron microscopy (SEM; brand Tescan, model Vega3). The laser diffraction technique was used to measure particle size distribution using an SZ-100 series (HORIBA Scientific) nanoparticle analyzer [30].

Hysteresis plots were measured at room temperature using a vibrating sample magnetometer (VSM, Lake Shore model 7404), with a maximum applied magnetic field of $13700 \mathrm{G}$. Saturation magnetization $\left(\mathrm{M}_{\mathrm{s}}\right)$, remaining magnetization $\left(\mathrm{M}_{\mathrm{r}}\right)$, and coercive field $\left(\mathrm{H}_{\mathrm{c}}\right)$ were the properties obtained from this experiment [30].

The acidity of the catalyst was determined through desorption analysis at the programmed ammonia temperature (TPD- $\mathrm{NH}_{3}$ ) in the SAMP3 multipurpose analysis system. Approximately $100 \mathrm{mg}$ of sample was pretreated at $400{ }^{\circ} \mathrm{C}$ under a helium atmosphere $\left(30 \mathrm{~mL} \cdot \mathrm{min}^{-1}\right)$. Then, the temperature was reduced to $100^{\circ} \mathrm{C}$, and the sample was subjected to an ammonia current for chemical adsorption for $45 \mathrm{~min}$. In the final step of the adsorption process, $\mathrm{NH}_{3}$ molecules were removed at $100^{\circ} \mathrm{C}$ for $1 \mathrm{~h}$, with the helium flow rate at $30 \mathrm{~mL} \cdot \mathrm{min}^{-1}$. The thermograms were obtained on heating (from 100 to $800{ }^{\circ} \mathrm{C}$ ) at $10^{\circ} \mathrm{C} \cdot \mathrm{min}^{-1}$ under a helium flow rate of $30 \mathrm{~mL} \cdot \mathrm{min}^{-1}$ [30].

Thermogravimetric analysis (TG/DTG) was performed using Perkin Elmer STA 6000 TG-DTA equipment in an $\mathrm{N}_{2}$ atmosphere, with the flow of $20 \mathrm{~mL} \cdot \mathrm{min}^{-1}$ and heating rate of $10{ }^{\circ} \mathrm{C} \cdot \mathrm{min}^{-1}$, using $10 \mathrm{mg}$ of sample in an alumina crucible, and a temperature range from 30 to $850^{\circ} \mathrm{C}[30,36-38]$.

FTIR spectra between 4000 and $200 \mathrm{~cm}^{-1}$ were obtained using a BRUKER Vertex 70 spectrometer, with 64 scans. The FTIR spectra were recorded in transmittance units in the wavenumber range.

Raman spectra were recorded on a RENISHAW spectrophotometer (model InVia Raman microscope) using an $\mathrm{Ar}^{+}$laser, with a power of $100 \mathrm{~mW}$ and a wavelength of $514 \mathrm{~nm}$. The 50x objective was used.

The percentages of methyl or ethyl esters were determined via gas chromatography, using a chromatograph (VARIAN 450c) instrument with a flame ionization detector and a capillary column as the stationary phase (Varian Ultimetal "Select Biodiesel Glycerides RG"; dimensions: $15 \mathrm{~m} \times 0.32 \mathrm{~mm}$ $\times 0.45 \mathrm{~mm}$ ). The initial injection temperature was $100^{\circ} \mathrm{C}$, the oven temperature was $180^{\circ} \mathrm{C}$, and the detector operated at a temperature of $380^{\circ} \mathrm{C}[30]$.

The acidity index (official AOCS method, Cd 3d-63) was used to characterize both the residual oil and the products resulting from the catalytic tests. It was possible to quantify the mass yield of synthesized FAAEs, considering the initial mass of the residual oil in the TES reaction, assuming that 
the complete reaction of a specified amount $(x)$ of residual oil leads to the achievement of $100 \%$ yield mass $(X)$ of FAAEs. Therefore, the percentages of mass yields were defined and calculated as the values that express the reactions' final products' masses after the purification processes [30].

\section{Results and Discussion}

\subsection{Characterization of the $\mathrm{ZnO}-\mathrm{Ni}_{0.5} \mathrm{Zn}_{0.5} \mathrm{Fe}_{2} \mathrm{O}_{4}$ Catalyst}

\subsubsection{X-ray Diffraction}

Figure 1 shows the $\mathrm{X}$-ray diffractograms of the $\mathrm{ZnO}-\mathrm{Ni}_{0.5} \mathrm{Zn}_{0.5} \mathrm{Fe}_{2} \mathrm{O}_{4}$ catalyst heat-treated at different temperatures $\left(650,700\right.$, and $\left.800{ }^{\circ} \mathrm{C}\right)$. In summary, the synthesized catalyst showed a heterogeneous composition, confirming its polyphasic character (Figure 1a). It was also observed that the reverse spinel phase of Ni-Zn ferrite was a major phase, and there an evolution in this phase with an increase in the firing temperature (Figure $1 b, c)$. When the firing temperature increased from 650 to $700{ }^{\circ} \mathrm{C}$, there was a decrease in the secondary phases of $\mathrm{ZnO}(\mathrm{Z})$ and $\mathrm{Fe}_{2} \mathrm{O}_{3}(\mathrm{H})$, as well as a significant crystallization of the $\mathrm{Ni}-\mathrm{Zn}$ phase. However, the catalysts treated at these temperatures $\left(650\right.$ and $\left.700{ }^{\circ} \mathrm{C}\right)$ were still polyphasic, with discrete peaks in the secondary phases $\left(\mathrm{ZnO}\right.$ and $\left.\mathrm{Fe}_{2} \mathrm{O}_{3}\right)$. The $\mathrm{Fe}_{2} \mathrm{O}_{3}$ phase was identified using the standard JCPDS 40-1139 card, while the $\mathrm{ZnO}$ phase was detected according to the standard card JCPDS 36-1451.

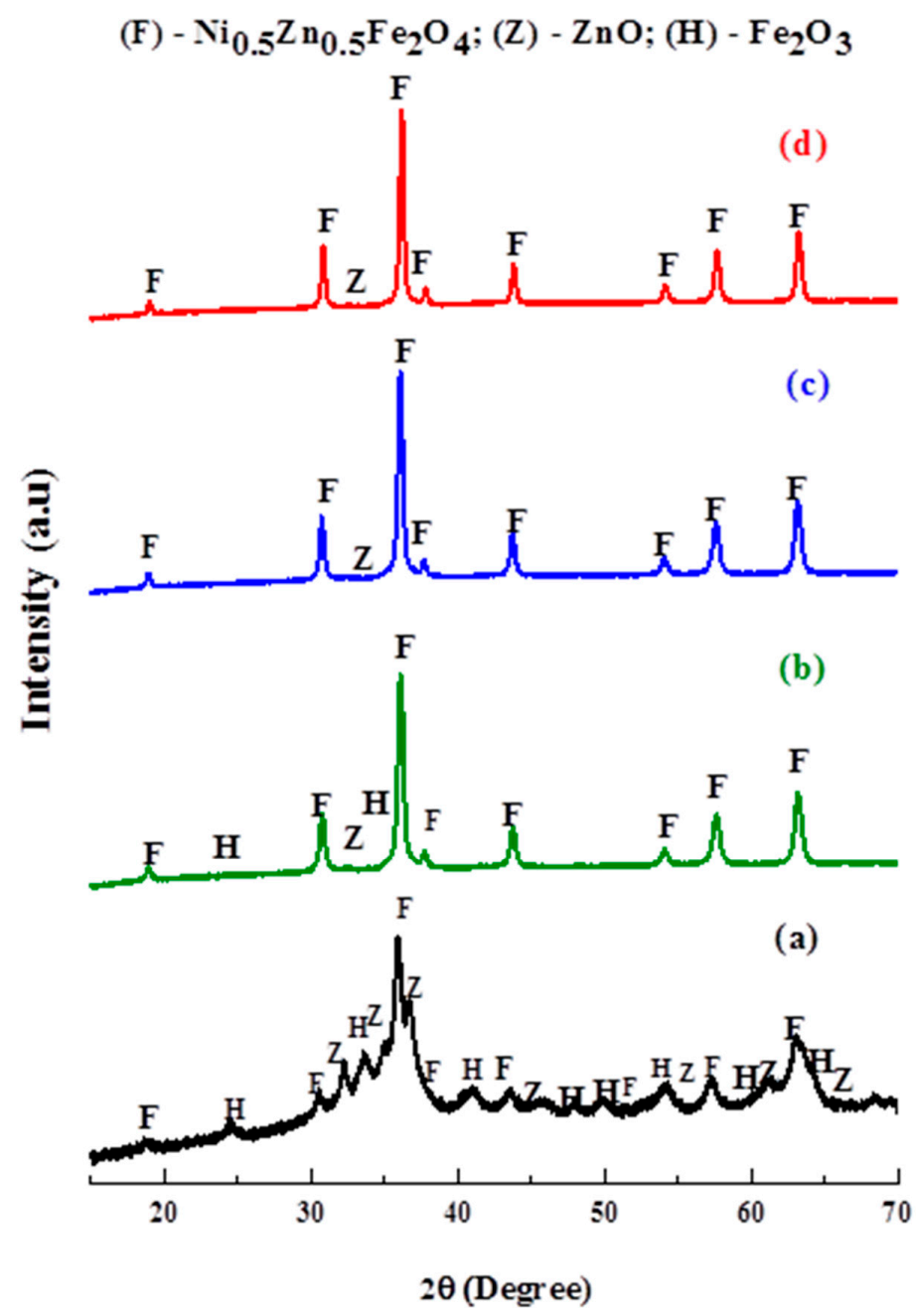

Figure 1. X-ray diffractograms of the catalyst $\mathrm{ZnO}-\mathrm{Ni}_{0.5} \mathrm{Zn}_{0.5} \mathrm{Fe}_{2} \mathrm{O}_{4}$ : (a) without heat-treatment; (b) $650{ }^{\circ} \mathrm{C}$ heat-treatment; (c) heat-treatment of $700{ }^{\circ} \mathrm{C}$; (d) heat-treatment of $800{ }^{\circ} \mathrm{C}$. 
Figure 1 shows that the phase of interest was synthesized at relatively low temperatures since Olhero et al. [39] synthesized Ni-Zn ferrite by coprecipitation and evaluated the evolution of the crystalline phases of the system. The authors found that the phase of interest only formed at $1200^{\circ} \mathrm{C}$. On the other hand, Hajalilou et al. [40] developed a Ni-Zn system by high-energy grinding; however, the experimental procedure has a relatively high cost and takes a long time since that the samples wait for an estimated time of $30 \mathrm{~h}$ to be subjected to a high-energy grind in a controlled atmosphere of oxygen for $2 \mathrm{~h}$, with the phase of interest being obtained at $500{ }^{\circ} \mathrm{C}$.

Still, in Figure 1, it was observed that a firing temperature equal to $800^{\circ} \mathrm{C}$ was enough to obtain a catalyst with a composition formed mostly of the $\mathrm{ZnO}-\mathrm{Ni}_{0.5} \mathrm{Zn}_{0.5} \mathrm{Fe}_{2} \mathrm{O}_{4}$ phase (Figure 1d). It is worth mentioning that the firing time used was only $5 \mathrm{~min}$. The synthesis was simple, fast, and does not add high energy expenditure nor high costs, as described in the literature $[39,40]$. The heat treatment performed at $800{ }^{\circ} \mathrm{C}$ was sufficient to obtain the $\mathrm{ZnO}-\mathrm{Ni}_{0.5} \mathrm{Zn}_{0.5} \mathrm{Fe}_{2} \mathrm{O}_{4}$ biphasic catalyst, with a high degree of crystallinity. Thus, it is possible to conclude that the experimental procedure (combustion reaction in pilot-scale) used to obtain the biphasic catalyst has technological potential. The crystallite size and crystallinity of the $\mathrm{ZnO}-\mathrm{Ni}_{0.5} \mathrm{Zn}_{0.5} \mathrm{Fe}_{2} \mathrm{O}_{4}$ biphasic catalyst, heat-treated at different temperatures $\left(650,700\right.$, and $\left.800^{\circ} \mathrm{C}\right)$, are listed in Table 1 .

Table 1. Crystallinity and crystallite size of the $\mathrm{ZnO}-\mathrm{Ni}_{0.5} \mathrm{Zn}_{0.5} \mathrm{Fe}_{2} \mathrm{O}_{4}$ biphasic catalyst without heat treatment and heat-treatment at 650,700 , and $800{ }^{\circ} \mathrm{C}$, respectively.

\begin{tabular}{|c|c|c|}
\hline Sample & Medium Crystallinity (\%) & Average Crystallite Size (nm) \\
\hline $\mathrm{ZnO}-\mathrm{Ni}_{0.5} \mathrm{Zn}_{0.5} \mathrm{Fe}_{2} \mathrm{O}_{4}-\mathrm{Fe}_{2} \mathrm{O}_{3}$ & 43.0 & 25.0 \\
\hline $\mathrm{ZnO}-\mathrm{Ni}_{0.5} \mathrm{Zn}_{0.5} \mathrm{Fe}_{2} \mathrm{O}_{4}-\mathrm{Fe}_{2} \mathrm{O}_{3}\left(650^{\circ} \mathrm{C}\right)$ & 46.5 & 22.8 \\
\hline $\mathrm{ZnO}-\mathrm{Ni}_{0.5} \mathrm{Zn}_{0.5} \mathrm{Fe}_{2} \mathrm{O}_{4}-\mathrm{Fe}_{2} \mathrm{O}_{3}\left(700^{\circ} \mathrm{C}\right)$ & 44.4 & 26.5 \\
\hline $\mathrm{ZnO}-\mathrm{Ni}_{0.5} \mathrm{Zn}_{0.5} \mathrm{Fe}_{2} \mathrm{O}_{4}\left(800{ }^{\circ} \mathrm{C}\right)$ & 54.7 & 32.0 \\
\hline
\end{tabular}

The $\mathrm{ZnO}-\mathrm{Ni}_{0.5} \mathrm{Zn}_{0.5} \mathrm{Fe}_{2} \mathrm{O}_{4}$ catalyst, heat-treated at $800{ }^{\circ} \mathrm{C}$, presented an average crystallinity of $54 \%$, close to the experimental values found in the literature [41]. The crystallite size, determined from the XRD data, was $32 \mathrm{~nm}$, indicating its nanometric character ( $\leq 100 \mathrm{~nm})$ [12]. The crystallite size of the $\mathrm{ZnO}-\mathrm{Ni}_{0.5} \mathrm{Zn}_{0.5} \mathrm{Fe}_{2} \mathrm{O}_{4}$ catalyst is within the crystallite size range of $7.23-46 \mathrm{~nm}$, as reported by $\mathrm{Li}$ et al. [42], who studied a similar system $\left(\mathrm{ZnFe}_{2} \mathrm{O}_{4}\right)$ synthesized by the combustion method. It is also possible to notice that the heat treatment applied slightly increased the structural parameters of the catalyst, evolving from $43.0 \%$ to $54.7 \%$ in crystalline percentage and from 25.0 to $32 \mathrm{~nm}$ in terms of crystallite size.

Figure 2 shows the X-ray diffractogram and Rietveld analysis of the $\mathrm{ZnO}-\mathrm{Ni}_{0.5} \mathrm{Zn}_{0.5} \mathrm{Fe}_{2} \mathrm{O}_{4}$ catalyst synthesized at $800^{\circ} \mathrm{C}$. The experimental points (blue and black) were adjusted to the intensity (red line) with the aid of the TOPAS program, according to ICDD card 184163 for Ni-Zn ferrite and ICSD card 26170 for $\mathrm{ZnO}$. It was observed that the $\mathrm{ZnO}-\mathrm{Ni}_{0.5} \mathrm{Zn}_{0.5} \mathrm{Fe}_{2} \mathrm{O}_{4}$ catalyst $\left(800^{\circ} \mathrm{C}\right)$ presented peaks that are characteristic of the major phase of spinel (Ni- $\mathrm{Zn}$ ferrite). However, the $\mathrm{ZnO}-\mathrm{Ni}_{0.5} \mathrm{Zn}_{0.5} \mathrm{Fe}_{2} \mathrm{O}_{4}$ system presented a higher percentage of the $\mathrm{Ni}-\mathrm{Zn}$ phase and, at the same time, a nonsignificant amount of zinc oxide $(0.46 \%)$.

The network parameters and percentage quantities of the phases in the $\mathrm{ZnO}-\mathrm{Ni}_{0.5} \mathrm{Zn}_{0.5} \mathrm{Fe}_{2} \mathrm{O}_{4}$ catalyst $\left(800^{\circ} \mathrm{C}\right)$ are shown in Table 2 . It was observed that the calculated value of the lattice parameter was $8.38 \AA$, which is close to the theoretical (8.3827 $\AA$; JCPDS card 52-0278) and experimental values (8.35 $\AA$; [43]) already reported. Additionally, it was possible to observe the maintenance of the unit cell with cubic symmetry, suggesting that there was no structural change due to the high proportion of $\mathrm{Ni}-\mathrm{Zn}$ ferrite. Regarding phase quantification, the presence of the Ni-Zn ferrite phase in high quantity (99.54\%) and segregated $\mathrm{ZnO}$ phases $\left(0.46 \%\right.$ ) were identified in the $\mathrm{ZnO}-\mathrm{Ni}_{0.5} \mathrm{Zn}_{0.5} \mathrm{Fe}_{2} \mathrm{O}_{4}$ catalyst that was heat-treated at $800{ }^{\circ} \mathrm{C}$, which is in agreement with the XRD results (see Figure 1). 


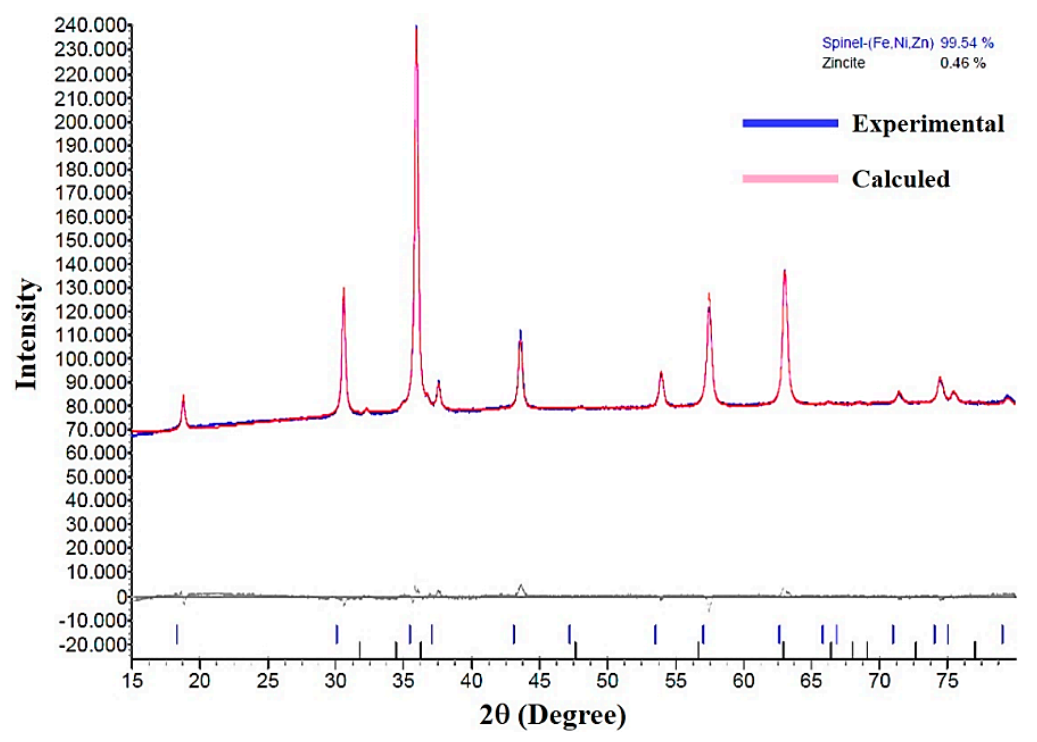

Figure 2. Refined X-ray diffractogram for the $\mathrm{ZnO}-\mathrm{Ni}_{0.5} \mathrm{Zn}_{0.5} \mathrm{Fe}_{2} \mathrm{O}_{4}$ catalyst $\left(800{ }^{\circ} \mathrm{C}\right)$.

Table 2. Quantification of phases presents in the $\mathrm{ZnO}-\mathrm{Ni}_{0.5} \mathrm{Zn}_{0.5} \mathrm{Fe}_{2} \mathrm{O}_{4}$ catalyst $\left(800{ }^{\circ} \mathrm{C}\right)$, with refinement by Rietveld.

\begin{tabular}{|c|c|c|c|c|c|c|}
\hline Sample & $\begin{array}{c}\text { Lattice } \\
\text { Parameters }\end{array}$ & Crystal System & $\begin{array}{c}\text { Percentage of } \\
\text { Phases Present }(\%)\end{array}$ & $\mathbf{R}_{\mathrm{wp}}$ & $\mathbf{R}_{\text {exp }}$ & GOF \\
\hline \multirow{2}{*}{$\begin{array}{c}\mathrm{ZnO}-\mathrm{Ni}_{0.5} \mathrm{Zn}_{0.5} \mathrm{Fe}_{2} \mathrm{O}_{4} \\
\left(800^{\circ} \mathrm{C}\right)\end{array}$} & $\begin{array}{c}\mathrm{a}=\mathrm{b}=\mathrm{c}=8.38 \\
\text { Referência }{ }^{1} \\
\mathrm{a}=\mathrm{b}=\mathrm{c}=8.38\end{array}$ & $\begin{array}{l}\text { Cubic }(\mathrm{Ni}-\mathrm{Zn}) \\
\text { ferrite }\end{array}$ & 99.54 & 0.92 & 0.35 & 2.61 \\
\hline & $\begin{array}{c}\mathrm{a}=3.24 \text { e } \mathrm{c}=5.19 \\
\text { Referência } \\
\mathrm{a}=3.24 \text { e } \mathrm{c}=5.20\end{array}$ & Hexagonal $\mathrm{ZnO}$ & 0.46 & & & \\
\hline
\end{tabular}

The goodness-of-it (GOF) and the weighted (Rwp) and expected (Rexp) indices are the parameters that indicate quality for Rietveld refinement. When $R_{w p}$ and $R_{\exp }$ values are close, they have the same trend, so it is possible to consider the refinement as satisfactory. Finally, refinement is considered satisfactory if the goodness-of-fit (GOF) is less than 1.7. In practice, values below 5 reflect an optimized refinement, as reported in the literature [44,45]. Therefore, based on the refinement results showed in Table 2, it can be considered that the results obtained were satisfactory for the $\mathrm{ZnO}-\mathrm{Ni}_{0.5} \mathrm{Zn}_{0.5} \mathrm{Fe}_{2} \mathrm{O}_{4}$ catalyst.

\subsubsection{Texture Analysis}

Figure 3 shows the adsorption/desorption isotherms of $\mathrm{N}_{2}$ due to the textural characterization of the $\mathrm{ZnO}-\mathrm{Ni}_{0.5} \mathrm{Zn}_{0.5} \mathrm{Fe}_{2} \mathrm{O}_{4}$ catalyst $\left(800{ }^{\circ} \mathrm{C}\right)$. It is observed that the catalyst presented a subtle hysteresis, which is characteristic of mesoporous materials. Besides the existence of hysteresis, mesoporous materials are also characterized by the absence of nitrogen adsorption limitation, i.e., $\mathrm{P} / \mathrm{P} 0$ value is high $[41,46]$. According to the classification recommended by IUPAC, this isotherm behavior is of type III, which characterizes an adsorption process that occurs in nonporous or macroporous materials [30].

Concerning the hysteresis cycle (Figure 3), it is possible to observe a practically constant level for $\mathrm{P} / \mathrm{P} 0$ values up to $0.2 \mathrm{~cm}^{3} / \mathrm{g}$. After that, a branch of hysteresis in the region of high relative pressure, with a very steep slope, is observed. Such behavior is characteristic of an $\mathrm{H}_{3}$ type loop profile, generally associated with the nonrigid aggregates of particles, as seen later in the SEM imaging, originating pores in the slits. The literature [46] indicates that when the isotherm presents an inflection 
of approximately $0.2 \mathrm{~cm}^{3} / \mathrm{g}$ (relative pressure $\left(\mathrm{P} / \mathrm{P}_{0}\right)$ ), it indicates the presence of micropores in the morphological structure.

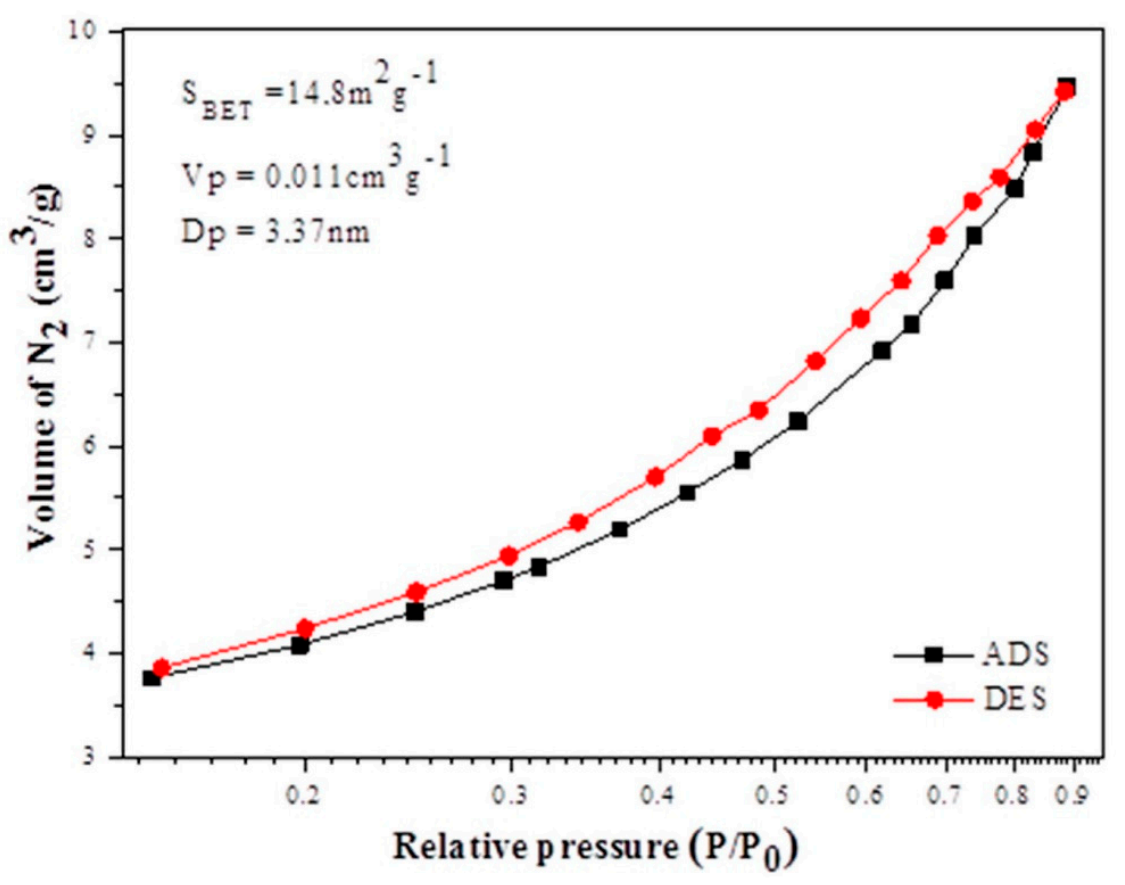

Figure 3. Adsorption/desorption isotherm measured from the $\mathrm{ZnO}-\mathrm{Ni}_{0.5} \mathrm{Zn}_{0.5} \mathrm{Fe}_{2} \mathrm{O}_{4}$ catalyst $\left(800{ }^{\circ} \mathrm{C}\right)$.

The average value of the specific surface area of the $\mathrm{ZnO}-\mathrm{Ni}_{0.5} \mathrm{Zn}_{0.5} \mathrm{Fe}_{2} \mathrm{O}_{4}$ catalyst $\left(800{ }^{\circ} \mathrm{C}\right)$ was around $14.8 \mathrm{~m}^{2} \mathrm{~g}^{-1}$, which is lower than the experimental values reported in the literature for $\mathrm{NiFe}_{2} \mathrm{O}_{4}$ [47]. However, for the $\mathrm{ZnO}-\mathrm{Ni}_{0.5} \mathrm{Zn}_{0.5} \mathrm{Fe}_{2} \mathrm{O}_{4}$ catalyst, when subjected to heat treatment, large particles are formed. This occurs due to the diffusion of atoms and the formation of the neck between the small and large particles, generating the growth of the particles [48,49]. Moreover, the pore diameter $(3.37 \mathrm{~nm})$ and the isotherms' profiles corroborate to indicate that the synthesized catalyst has a disorderly surface characteristic, with nonporous regions and other regions that present mesopores or macropores of different shapes and sizes [50].

\subsubsection{Scanning Electron Microscopy (SEM)}

Figure 4 shows the SEM images acquired from the $\mathrm{ZnO}-\mathrm{Ni}_{0.5} \mathrm{Zn}_{0.5} \mathrm{Fe}_{2} \mathrm{O}_{4}$ catalyst that was heat-treated at $800{ }^{\circ} \mathrm{C}$. It was observed that the $\mathrm{ZnO}-\mathrm{Ni}_{0.5} \mathrm{Zn}_{0.5} \mathrm{Fe}_{2} \mathrm{O}_{4}$ catalyst presented irregular agglomerates (Figure 4a) with pores in its surface. Clusters (Figure 4a) and particles (Figure 4b) were observed in the SEM images, with sizes close to 100 and $10 \mu \mathrm{m}$, respectively. The diffusion of small particles occurred with the consequent agglomeration of them on the large particles' surface. This indicates that the heat treatment caused the diffusion of small particles and, consequently, caused the growth of the agglomerates, corroborating with the results of the specific surface area presented in the textural analysis.

\subsubsection{Granulometric Analysis}

Figure 5 shows the distribution and accumulated distribution curves measured from the $\mathrm{ZnO}-\mathrm{Ni}_{0.5} \mathrm{Zn}_{0.5} \mathrm{Fe}_{2} \mathrm{O}_{4}$ catalyst synthesized at $800{ }^{\circ} \mathrm{C}$. It was observed that the accumulative distribution curve of the clusters (blue curve) and the frequency histogram of the distribution of the populations of clusters present the same particle diameter (histogram in black). In summary, the $\mathrm{ZnO}-\mathrm{Ni}_{0.5} \mathrm{Zn}_{0.5} \mathrm{Fe}_{2} \mathrm{O}_{4}$ catalyst, heat-treated at $800{ }^{\circ} \mathrm{C}$, showed a relatively wide particle size distribution, corroborating with the SEM images (Figure 4). In addition, symmetrical and 
monomodal behavior was identified, with an average diameter (50\% in the accumulated curve) of $39.58 \mathrm{~nm}$. When this value is compared with the crystallite size $(32 \mathrm{~nm})$, it appears that the value obtained in the particle size distribution for D50 was higher. This indicates that the synthesized material has irregular nanometer-sized clusters.

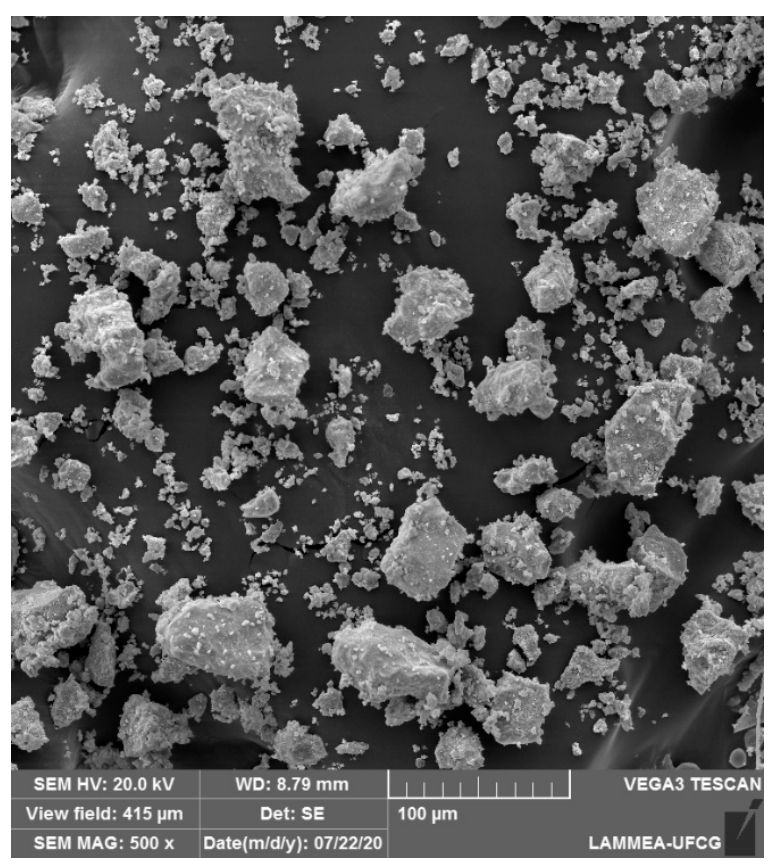

(a)

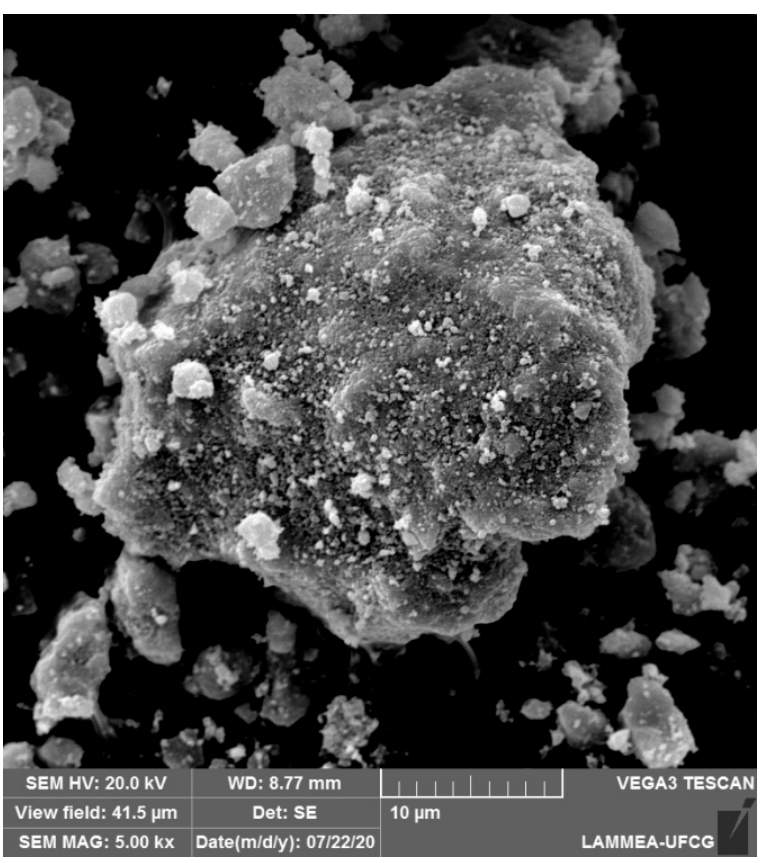

(b)

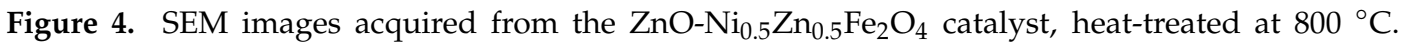
The magnifications used were $500 \times(\mathbf{a})$ and $5000 \times(\mathbf{b})$.

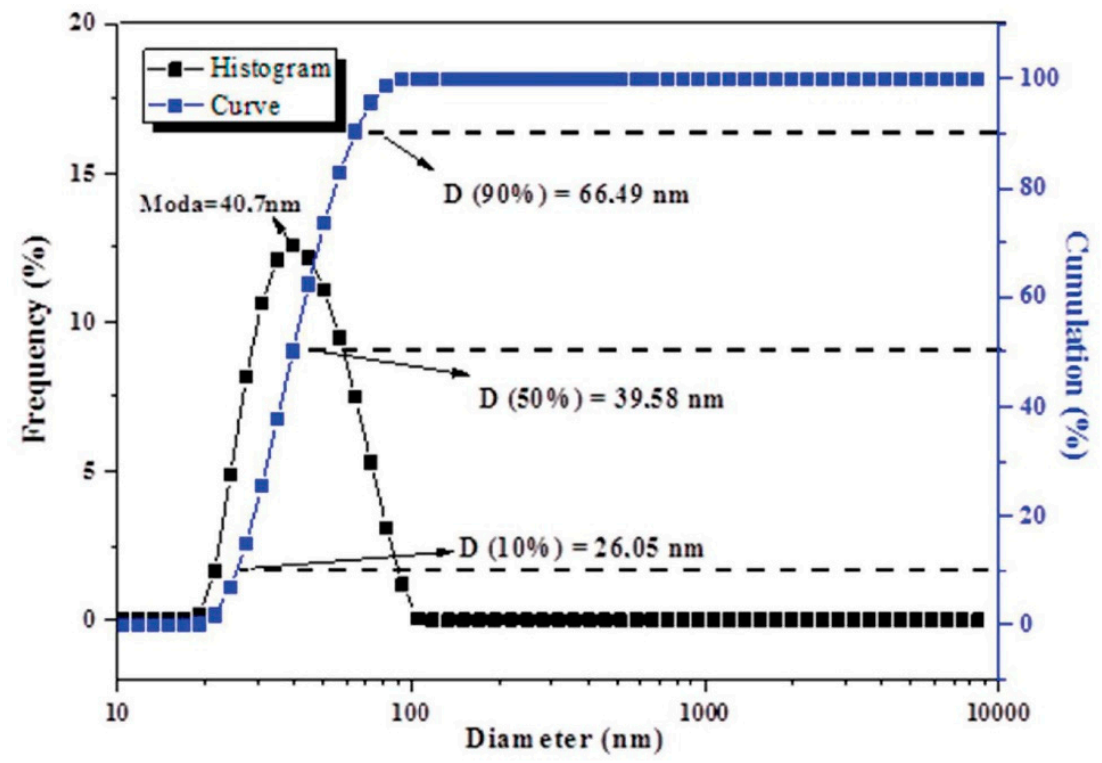

Figure 5. The particle size distribution of the $\mathrm{ZnO}-\mathrm{Ni}_{0.5} \mathrm{Zn}_{0.5} \mathrm{Fe}_{2} \mathrm{O}_{4}$ catalyst, heat-treated at $800{ }^{\circ} \mathrm{C}$.

\subsubsection{Fourier Transform Infrared Spectroscopy (FTIR) and Raman}

Figure 6a,b shows the FTIR and Raman spectrums measured from the $\mathrm{ZnO}-\mathrm{Ni}_{0.5} \mathrm{Zn}_{0.5} \mathrm{Fe}_{2} \mathrm{O}_{4}$ catalyst, heat-treated at $800^{\circ} \mathrm{C}$. Figure 6a shows bands below $1000 \mathrm{~cm}^{-1}$, characteristic of ferrites with a spinel-like crystalline structure [51]. Bands at 537 and $449 \mathrm{~cm}^{-1}$ were also observed and are attributed to the 
tetrahedral and octahedral forms of $\mathrm{ZnO}-\mathrm{Ni}_{0.5} \mathrm{Zn}_{0.5} \mathrm{Fe}_{2} \mathrm{O}_{4}$, which is in agreement with the XRD experiments (see Figure 1). As shown in the literature [52], the vibrational frequency around $600-500 \mathrm{~cm}^{-1}$ is related to the $\mathrm{Fe}^{3+} \mathrm{O}^{2-}$ complex at the tetrahedral site. On the other hand, the vibrational frequency around $450-350 \mathrm{~cm}^{-1}$ is related to the $\mathrm{Fe}^{3+} \mathrm{O}^{2-}$ and $\mathrm{M}^{2+} \mathrm{O}^{2-}$ complexes (where $\mathrm{M}^{2+}=\mathrm{Zn}^{2+}, \mathrm{Mn}^{2+}, \mathrm{Fe}^{2+}$ ) at the octahedral site.

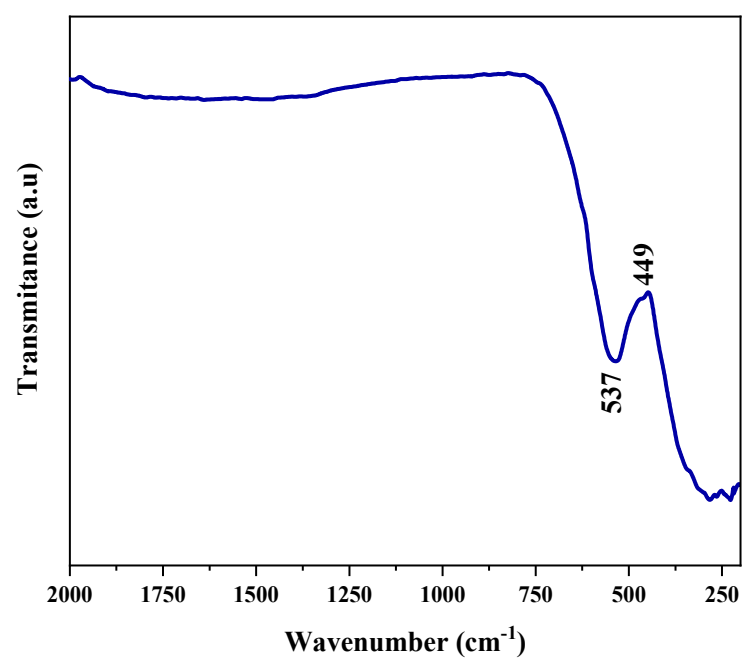

(a)

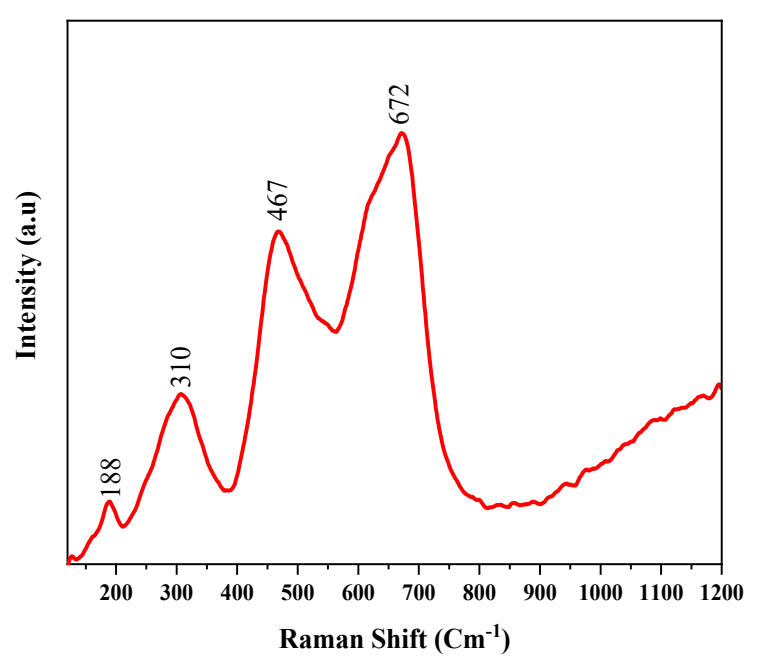

(b)

Figure 6. (a) FTIR spectrum and (b) Raman spectrum measured from the $\mathrm{ZnO}-\mathrm{Ni}_{0.5} \mathrm{Zn}_{0.5} \mathrm{Fe}_{2} \mathrm{O}_{4}$ catalyst, heat-treated at $800{ }^{\circ} \mathrm{C}$.

In Figure $6 \mathrm{~b}$, the bands near $200\left(\mathrm{~F}_{2 \mathrm{~g} 1}\right), 310\left(\mathrm{E}_{\mathrm{g}}\right), 467\left(\mathrm{~F}_{2 \mathrm{~g} 2}\right)$, and $672\left(\mathrm{~A}_{1 \mathrm{~g}}\right) \mathrm{cm}^{-1}$ are characteristic of the $\mathrm{ZnO}-\mathrm{Ni}_{0.5} \mathrm{Zn}_{0.5} \mathrm{Fe}_{2} \mathrm{O}_{4}$ catalyst [53]. The $\mathrm{A}_{1 \mathrm{~g}}$ mode is related to the symmetrical stretching of the oxygen atoms in the Fe-O bonds (tetrahedral bonds). The $\mathrm{E}_{\mathrm{g}}$ and $\mathrm{F}_{2 \mathrm{~g} 1}$ bands are related to the symmetrical flexion of oxygen concerning Fe and the entire tetrahedron's translational movement. Lastly, the $\mathrm{F}_{2 \mathrm{~g} 2}$ band occurs due to the asymmetric elongation of the Fe-O bond. Raman spectrum agrees with the XRD results since it was also possible to identify the major presence of ferrite. However, unlike the Rietveld analysis, bands related to the $\mathrm{ZnO}$ phase were not identified. This is probably related to the low concentration of that phase in the synthesized catalyst at $800{ }^{\circ} \mathrm{C}$.

\subsubsection{Thermogravimetry (TG)}

Figure 7 shows the TG and DTG curves measured from the $\mathrm{ZnO}-\mathrm{Ni}_{0.5} \mathrm{Zn}_{0.5} \mathrm{Fe}_{2} \mathrm{O}_{4}$ catalyst, heat-treatment at $800{ }^{\circ} \mathrm{C}$. The thermal profile showed that it was possible to identify three decomposition stages, with a total loss of mass of $2.1 \%$. The first stage occurred in the range of 36- $100{ }^{\circ} \mathrm{C}$ and is related to spontaneous evaporation of the free water absorbed on the catalyst surface. The second stage occurred at $211-314^{\circ} \mathrm{C}$ and corresponded to the loss of mass due to the continuous oxidation of organic matter and inorganic salt decomposition. The third stage occurred between 546 and $596^{\circ} \mathrm{C}$, corroborating the mass loss seen in the literature [54].

\subsubsection{Magnetic Evaluation}

The magnetic behavior of the $\mathrm{ZnO}-\mathrm{Ni}_{0.5} \mathrm{Zn}_{0.5} \mathrm{Fe}_{2} \mathrm{O}_{4}$ catalyst, heat-treated at $800^{\circ} \mathrm{C}$, was evaluated from the magnetization $(\mathrm{M})$ versus magnetic field $(\mathrm{H})$ curve (see Figure 8). Due to the low values of remaining magnetization $(6.0 \mathrm{my} / \mathrm{g})$ and coercivity $(0.06(\mathrm{G}))$, it is possible to see that the $\mathrm{ZnO}-\mathrm{Ni}_{0.5} \mathrm{Zn}_{0.5} \mathrm{Fe}_{2} \mathrm{O}_{4}$ catalyst presents a soft magnetic behavior (i.e., easily magnetizes and demagnetizes. The hysteresis curve presents a well-defined $S$ shape and a very narrow internal area, suggesting the catalyst studied has ferrimagnetic behavior [55]. The maximum saturation magnetization was $59.4 \mathrm{emu} / \mathrm{g}$, higher than the values already 
reported in the literature [12]. The heat treatment applied to synthesize the $\mathrm{ZnO}-\mathrm{Ni}_{0.5} \mathrm{Zn}_{0.5} \mathrm{Fe}_{2} \mathrm{O}_{4}$ catalyst favored a considerable increase in saturation magnetization.

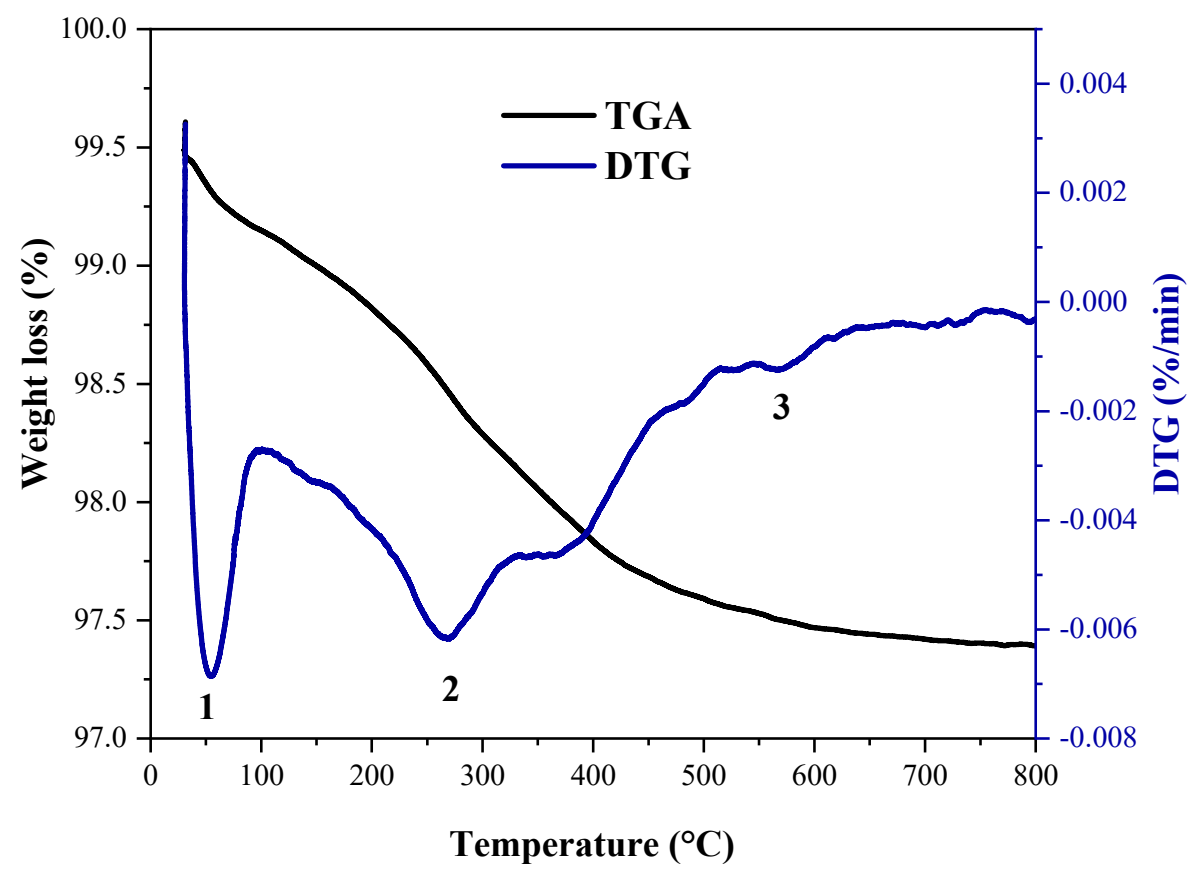

Figure 7. Thermal stability of the $\mathrm{ZnO}-\mathrm{Ni}_{0.5} \mathrm{Zn}_{0.5} \mathrm{Fe}_{2} \mathrm{O}_{4}$ catalyst, heat-treated at $800{ }^{\circ} \mathrm{C}$.

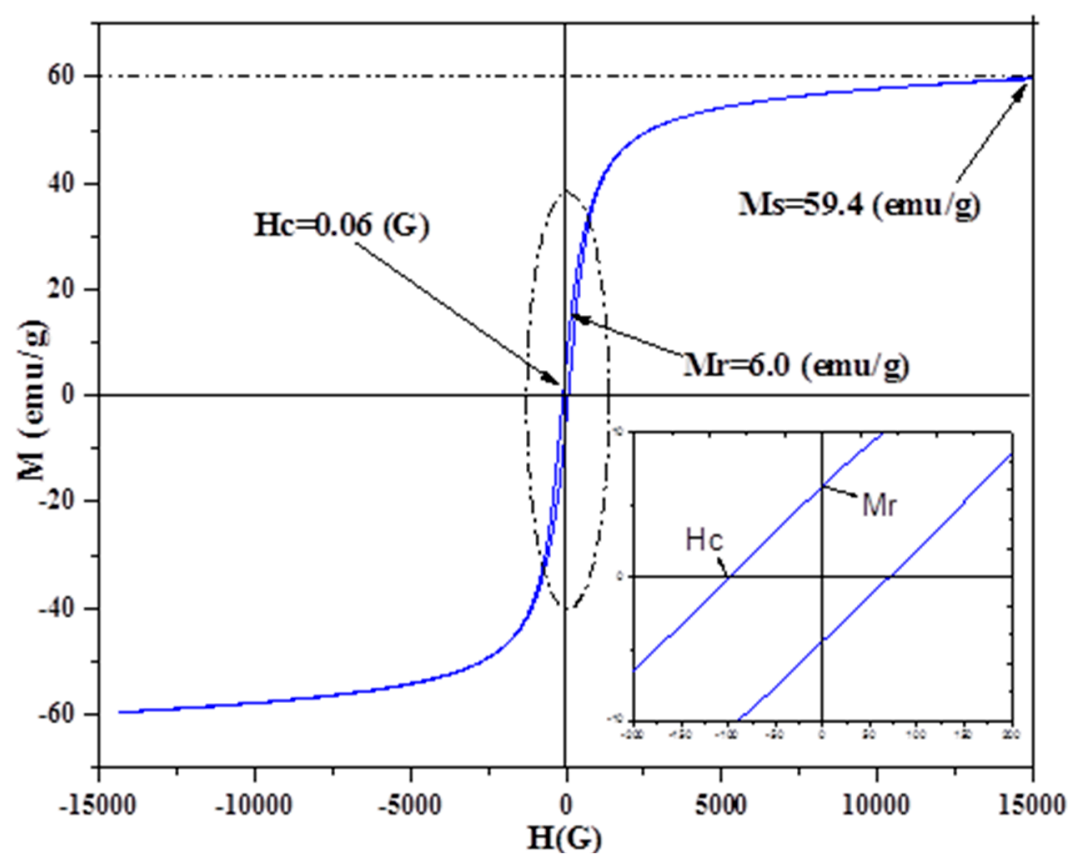

Figure 8. The magnetic hysteresis curve measured from the $\mathrm{ZnO}-\mathrm{Ni}_{0.5} \mathrm{Zn}_{0.5} \mathrm{Fe}_{2} \mathrm{O}_{4}$ catalyst, heat-treated at $800{ }^{\circ} \mathrm{C}$.

In general, Ni-Zn-based ferrites are ferrimagnetic; that is, they exhibit magnetic properties in the presence of an external magnetic field. However, when the external magnetic field is removed, it is impossible to observe coercivity or the remaining magnetization. In this way, Ni-Zn-based ferrites are easily removed from the suspension by applying an external magnetic field during the product separation process. Magnetic separation is a relevant alternative to filtration and/or centrifugation 
since it prevents the catalyst's loss and increases the capacity for reuse. As a consequence, there is a cost-benefit of the catalyst for industrial-scale production.

\subsection{8. $\mathrm{NH}_{3}$ Temperature Programmed Desorption Analysis (TPD)}

The active acid sites of the $\mathrm{ZnO}-\mathrm{Ni}_{0.5} \mathrm{Zn}_{0.5} \mathrm{Fe}_{2} \mathrm{O}_{4}$ catalyst $\left(800^{\circ} \mathrm{C}\right)$ were determined using TPD- $\mathrm{NH}_{3}$ analysis (see Figure 9). It is possible to see two $\mathrm{NH}_{3}$ desorption peaks in the $\mathrm{TPD}-\mathrm{NH}_{3}$ analysis, where the first peak $\left(\sim 218^{\circ} \mathrm{C}\right.$, corresponding to weak and moderate acidic sites) and the second peak $\left(\sim 525^{\circ} \mathrm{C}\right)$ are attributed to acidic sites of a strong nature. These results are in agreement with the literature [56,57].

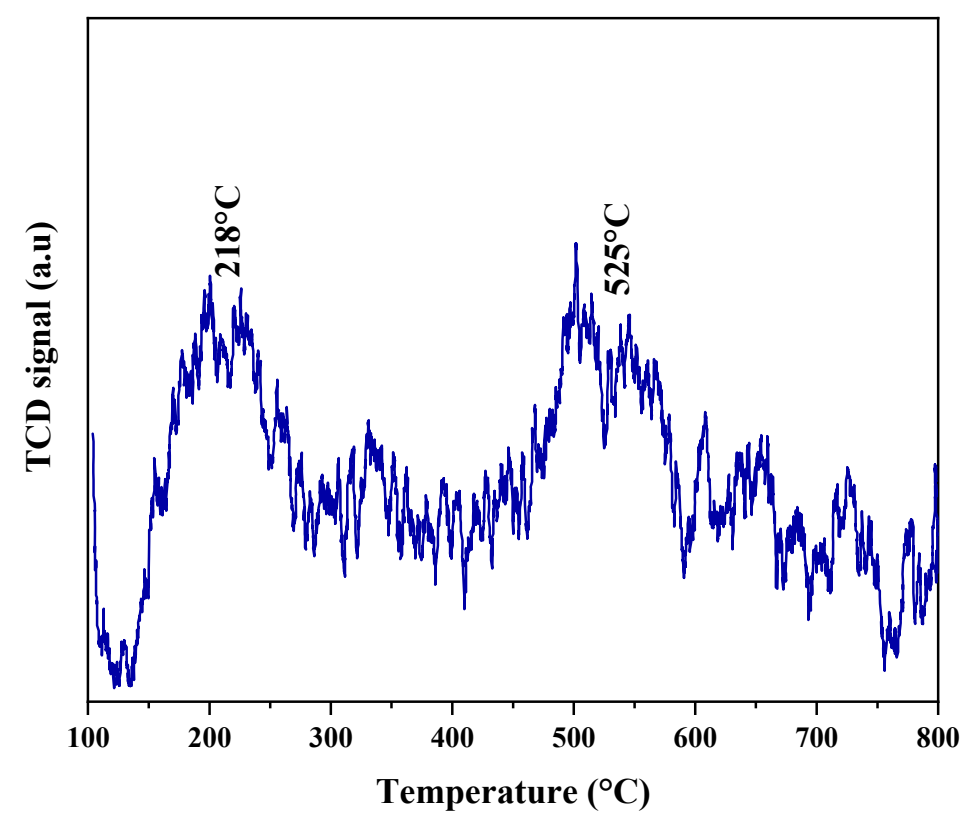

Figure 9. $\mathrm{TPD}-\mathrm{NH}_{3}$ analysis of the $\mathrm{ZnO}-\mathrm{Ni}_{0.5} \mathrm{Zn}_{0.5} \mathrm{Fe}_{2} \mathrm{O}_{4}$ catalyst $\left(800{ }^{\circ} \mathrm{C}\right)$.

The acidity of the $\mathrm{ZnO}-\mathrm{Ni}_{0.5} \mathrm{Zn}_{0.5} \mathrm{Fe}_{2} \mathrm{O}_{4}$ catalyst, heat-treated at $800{ }^{\circ} \mathrm{C}$, was calculated by integrating the deconvolution area from the TPD- $\mathrm{NH}_{3}$ curve. The result indicated two types of $\mathrm{NH}_{3}$ desorption sites: the first peak refers to weak and moderate acid sites, with a temperature range between $100{ }^{\circ} \mathrm{C}$ and $350{ }^{\circ} \mathrm{C}$; the other peak refers to the strong acidity sites that were identified between $450^{\circ} \mathrm{C}$ and $650^{\circ} \mathrm{C}$, corroborating with the literature [58]. Finally, the results obtained from the TPD- $\mathrm{NH}_{3}$ curve indicate a concentration of weak-moderate and strong acid sites, with $8.59 \mu \mathrm{mol} / \mathrm{g}$ and $10.13 \mu \mathrm{mol} / \mathrm{g}$ of $\mathrm{NH}_{3}$, respectively. Therefore, the studied $\mathrm{Ni}_{0.5} \mathrm{Zn}_{0.5} \mathrm{Fe}_{2} \mathrm{O}_{4}$ catalyst showed a total acidity of $18.72 \mu \mathrm{mol} / \mathrm{g}$ of $\mathrm{NH}_{3}$. Thus, it is possible to conclude that the $\mathrm{Ni}_{0.5} \mathrm{Zn}_{0.5} \mathrm{Fe}_{2} \mathrm{O}_{4}$ magnetic catalyst has an acidic character.

\subsubsection{Catalytic Performance}

Figure 10 shows the catalytic performance, acidity reduction, and mass yield of the $\mathrm{ZnO}-\mathrm{Ni}_{0.5} \mathrm{Zn}_{0.5} \mathrm{Fe}_{2} \mathrm{O}_{4}$ catalyst in TES reactions of the residual oil, performed in the presence of ethanol and methanol. At this moment, the dependent variable is the alcoholic route, with the following reaction conditions fixed-alcohol/oil ratio of 1/15, residual oil mass of $30 \mathrm{~g}$, the reaction time of $1 \mathrm{~h}$, temperature $200{ }^{\circ} \mathrm{C}$, and $3 \%$ catalyst percentage $(0.9 \mathrm{~g})$. The ester conversion was $73 \%$, and the mass yield was around $80 \%$ for the methyl alcoholic route. The ethyl route showed lower conversions, with $59.1 \%$ for the ester conversion and mass yield in approximately $70 \%$. The acidity of the FAAEs produced reduced significantly when using the methyl alcoholic route (reaching $90 \%$ ), while the ethyl route reached $-41 \%$, suggesting that a large part of the available raw material reacted to the test conditions. 


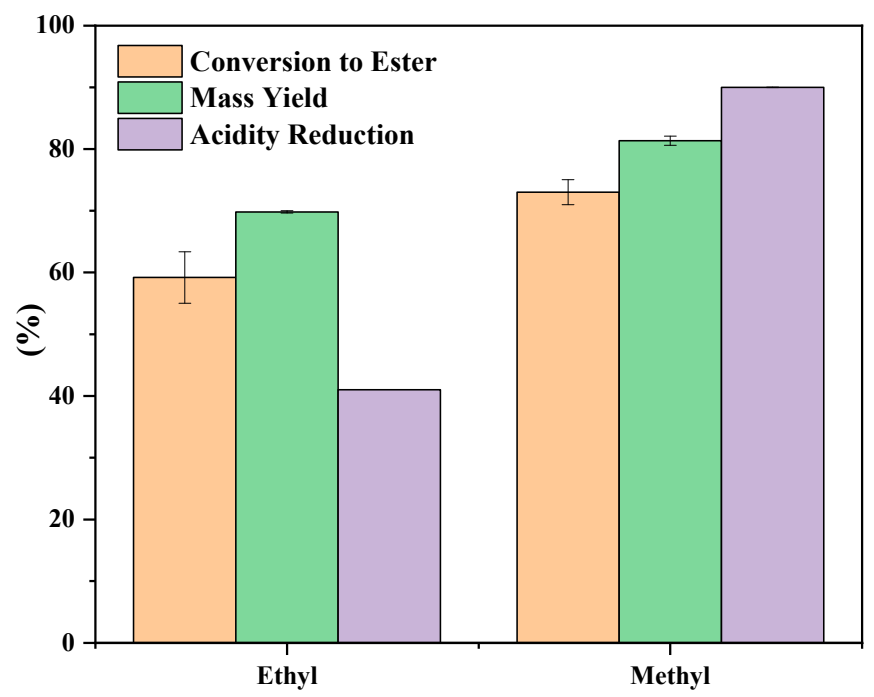

Alcoholic Route

Figure 10. Results of conversion to ester, yield in mass, and reduction of acidity in TES reactions in the presence of the $\mathrm{ZnO}-\mathrm{Ni}_{0.5} \mathrm{Zn}_{0.5} \mathrm{Fe}_{2} \mathrm{O}_{4}$ catalysts using residual oil.

In the TES reactions tested, there was a difference of approximately $14.29 \%$ in the conversion values in favor of methanol. Such behavior is probably due to the physical and chemical nature (short-chain and polarity) of methanol, leading to higher conversions than alcohol. Therefore, the type of alcohol used can be one factor for the disparity in the conversions resulting from the transesterification and esterification reactions since the other parameters involved in the processes, such as temperature and time, were kept unchanged [59]. Methanol is frequently used to obtain short-chains and polar, and the fact that it is free of water makes it easier to separate esters and glycerin, culminating in greater conversions. Thus, it is possible that the water present in ethanol interfered, for example, in the TES reaction by ethyl route, reducing the final reaction product (fatty acid ethyl esters). Consequently, it provided the formation of an emulsion in the mixture of esters due to the formation of insoluble fatty acids during the reaction process.

The results obtained in this work corroborate with those reported by Dantas et al. (2017) [60], in which $85 \%$ ester conversions were verified for transesterification of soybean oil. Mapossa et al. (2017) [12] found a low conversion to fatty acid ethyl esters when they tested the alcoholic ethylic route by esterifying the mixture of soybean oil oleic acid, showing conversions in the ester of 44.49, 43.09, and $43.95 \%$, respectively.

It is important to note that the quality standards of Brazilian biodiesel are established according to ANP 07/2008 (Brazil) and EN 14214 (European Union). These two standards determine the minimum and maximum concentration values for the different species present in the biodiesel produced. The ester content determined by following Brazilian and European standards is at least $96.5 \%$ of the FAAEs. Therefore, this study has shown that the maximum conversion of the ester content obtained was $73 \%$, which is close to the value established by regulatory standards, leading to the belief that if the reaction conditions used are changed, such as the molar ratio of alcohol:oil, amount of catalyst, and time and temperature, they can be potential candidates to optimize the biodiesel production process. Through this work, it was possible to develop the final product with a wide range of applications, contributing to the discovery and expansion of heterogeneous magnetic catalysts on a nanoscale, where the cost is relatively low, especially when using technological products aimed at society itself.

Figure 11 presents profiles of the percentage values of glyceride composition that was not converted in the reaction. The values were identified and quantified by gas chromatography analysis. 


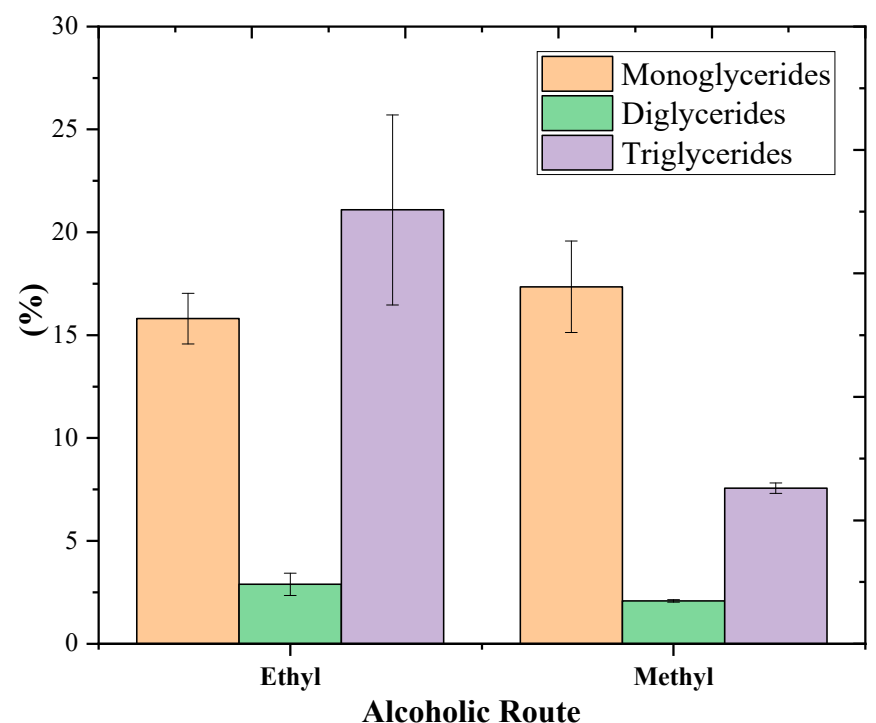

Figure 11. Result of the percentage of glycerides not converted to esters during the catalytic tests of the $\mathrm{ZnO}-\mathrm{Ni}_{0.5} \mathrm{Zn}_{0.5} \mathrm{Fe}_{2} \mathrm{O}_{4}$ catalyst by ethyl (Et) and methyl (Met) routes.

The comparison of Figures 10 and 11 shows that the synthesized catalyst shows catalytic activity, indicating that the esterification and transesterification reactions occur simultaneously. However, the methyl route was more effective in esterification due to the high percentages of free fatty acids consumed in the reaction. The similarity of the mass yield profiles (Figure 10) with the profiles of triglyceride residues not consumed in the reaction (Figure 11) suggest that the ethyl route has more significant reaction interference in transesterification, directing the reaction to the formation stages of mono- and diacylglycerides in higher percentages than the methyl route. Similar behavior was reported by Dantas et al. 2016 [12], who studied similar heterogeneous magnetic catalytic systems in a TES reaction performed by a mixture of refined soybean oil with oleic acid, which simulates the high acidity characteristic of residual oils due to large quantities of free fatty acids, tested by methyl and ethyl routes, which showed $91.4 \%$ and $77.8 \%$ conversion to methyl and ethyl esters, respectively.

\section{Conclusions}

The combustion reaction was sufficient to obtain the $\mathrm{ZnO}-\mathrm{Ni}_{0.5} \mathrm{Zn}_{0.5} \mathrm{Fe}_{2} \mathrm{O}_{4}$ magnetic catalyst and, subsequently, the heat-treatment at $800{ }^{\circ} \mathrm{C}$ favored a biphasic transformation. X-ray diffraction confirmed the inverse spinel majority phase's presence, with an average crystallite size of $32 \mathrm{~nm}$. The morphology was investigated by SEM images, which showed the clusters formed by irregular particles, confirming the particle size distribution. The catalyst revealed the typical ferrimagnetic behavior of soft materials, with a high saturation magnetization of $59.4 \mathrm{emu} / \mathrm{g}$. The $\mathrm{ZnO}-\mathrm{Ni}_{0.5} \mathrm{Zn}_{0.5} \mathrm{Fe}_{2} \mathrm{O}_{4}$ system was more catalytically active for the methyl route, with an average conversion of $73 \%$, while the ethyl route achieved a conversion of $59.1 \%$ into biodiesel. The use of the $\mathrm{ZnO}-\mathrm{Ni}_{0.5} \mathrm{Zn}_{0.5} \mathrm{Fe}_{2} \mathrm{O}_{4}$ catalyst for biodiesel production derived from residual oil was effective, with the viability of industrial production. In general, the transformation of an oil residue into biodiesel is important since it adds value to a discarded material. Additionally, the reuse of residual oil minimizes the environmental and social impacts, contributing to sustainable development.

Author Contributions: Conceptualization, C.B.B.L.; data curation, A.L.d.S., A.F.F.d.F., S.A.S.L.d.M., and S.M.P.M.; formal analysis, A.F.F.d.F., S.A.S.L.d.M., and S.M.P.M.; funding acquisition, A.C.F.d.M.C.; investigation, A.L.d.S. and C.B.B.L.; methodology, A.L.d.S.; project administration, A.C.F.d.M.C.; supervision, A.C.F.d.M.C.; validation, A.F.F.d.F., S.M.P.M., and A.C.F.d.M.C.; writing-review and editing, A.L.d.S., C.B.B.L., S.M.P.M., and A.M.R. All authors have read and agreed to the published version of the manuscript.

Funding: Coordenação de Aperfeiçoamento de Pessoal de Nível Superior (CAPES). 
Acknowledgments: The authors would like to thank the Coordenação de Aperfeiçoamento de Pessoal de Nível Superior (CAPES) for their financial support.

Conflicts of Interest: The authors declare no conflict of interest.

\section{References}

1. Luna, C.B.B.; Siqueira, D.D.; Ferreira, E.d.S.B.; da Silva, W.A.; Nogueira, J.A.d.S.; Araújo, E.M. From disposal to technological potential: Reuse of polypropylene waste from industrial containers as a polystyrene impact modifier. Sustainability 2020, 12, 5272. [CrossRef]

2. Sales, H.B.; Menezes, R.R.; Neves, G.A.; Souza, J.J.N.d.; Ferreira, J.M.; Chantelle, L.; Oliveira, A.L.M.d.; Lira, H.d.L. Development of Sustainable Heterogeneous Catalysts for the Photocatalytic Treatment of Effluents. Sustainability 2020, 12, 7393. [CrossRef]

3. Yadav, M.; Singh, V.; Sharma, Y.C. Methyl transesterification of waste cooking oil using a laboratory synthesized reusable heterogeneous base catalyst: Process optimization and homogeneity study of catalyst. Energy Conv. Manag. 2017, 148, 1438-1452. [CrossRef]

4. De Campos, T.M.P.; Antunes, M.C. Cadeia reversa do óleo de cozinha residual: O papel do Ponto de Entrega Voluntária (PEV). Dig. Re Vista 2018, 3, 96-111.

5. Lam, M.K.; Lee, K.T.; Mohamed, A.R. Homogeneous, heterogeneous and enzymatic catalysis for transesterification of high free fatty acid oil (waste cooking oil) to biodiesel: A review. Biotechnol. Adv. 2010, 28, 500-518. [CrossRef] [PubMed]

6. Tsai, W.T. Mandatory recycling of waste cooking oil from residential and commercial sectors in Taiwan. Resources 2019, 8, 38. [CrossRef]

7. Said, N.H.; Ani, F.N.; Said, M.F.M. Review of the production of biodiesel from waste cooking oil using solid catalysts. J. Mech. Eng. Sci. 2015, 8, 1302-1311. [CrossRef]

8. Li, M.; Chen, J.; Huang, Y.; Li, M.; Lin, X.; Qiu, T. Reusable and efficient heterogeneous catalysts for biodiesel production from free fatty acids and oils: Self-solidifying hybrid ionic liquids. Energy 2020, 211, 118631. [CrossRef]

9. Gopan, S.N.; Rajan, A.V.; Krishnan, B.R. Review of Bio-diesel production from waste cooking oil and analyze the IC engine performance. Mater. Today Proc. 2020. [CrossRef]

10. Mandolesi De Araújo, C.D.; De Andrade, C.C.; De Souza, E.; Silva, E.; Dupas, F.A. Biodiesel production from used cooking oil: A review. Renew. Sustain. Energy Rev. 2013, 27, 445-452. [CrossRef]

11. Wallace, T.; Gibbons, D.; O'Dwyer, M.; Curran, T.P. International evolution of fat, oil and grease (FOG) waste management-A review. J. Environ. Manag. 2017, 187, 424-435. [CrossRef] [PubMed]

12. Mapossa, A.B.; Dantas, J.; Diniz, V.C.S.; Silva, M.R.; Kiminami, R.H.G.A.; Costa, A.C.F.M.; Federal, U.; Grande, D.C.; Grande, C.; Africa, S. Síntese e caracterização do ferroespinélio $\mathrm{Ni}_{0.7} \mathrm{Zn}_{0.3} \mathrm{Fe}_{2} \mathrm{O}_{4}$ : Avaliação de desempenho na esterificação metílica e etílica. Cerâmica 2017, 63, 223-232. [CrossRef]

13. Enweremadu, C.C.; Mbarawa, M.M. Technical aspects of production and analysis of biodiesel from used cooking oil-A review. Renew. Sustain. Energy Rev. 2009, 13, 2205-2224. [CrossRef]

14. Tan, Y.H.; Abdullah, M.O.; Nolasco-Hipolito, C. The potential of waste cooking oil-based biodiesel using heterogeneous catalyst derived from various calcined eggshells coupled with an emulsification technique: A review on the emission reduction and engine performance. Renew. Sustain. Energy Rev. 2015, 47, 589-603. [CrossRef]

15. Wang, L.; Dong, X.; Jiang, H.; Li, G.; Zhang, M. Ordered mesoporous carbon supported ferric sulfate: A novel catalyst for the esterification of free fatty acids in waste cooking oil. Fuel Process. Technol. 2014, 128, 10-16. [CrossRef]

16. Lou, W.Y.; Zong, M.H.; Duan, Z.Q. Efficient production of biodiesel from high free fatty acid-containing waste oils using various carbohydrate-derived solid acid catalysts. Bioresour. Technol. 2008, 99, 8752-8758. [CrossRef]

17. Gardy, J.; Nourafkan, E.; Osatiashtiani, A.; Lee, A.F.; Wilson, K.; Hassanpour, A.; Lai, X. A core-shell $\mathrm{SO}_{4} / \mathrm{Mg}-\mathrm{Al}-\mathrm{Fe}_{3} \mathrm{O}_{4}$ catalyst for biodiesel production. Appl. Catal. B Environ. 2019, 259, 118093. [CrossRef] 
18. Liu, Y.; Zhang, P.; Fan, M.; Jiang, P. Biodiesel production from soybean oil catalyzed by magnetic nanoparticle $\mathrm{MgFe}_{2} \mathrm{O}_{4} @ \mathrm{CaO}$. Fuel 2016, 164, 314-321. [CrossRef]

19. Quah, R.V.; Tan, Y.H.; Mubarak, N.M.; Khalid, M.; Abdullah, E.C.; Nolasco-Hipolito, C. An overview of biodiesel production using recyclable biomass and non-biomass derived magnetic catalysts. J. Environ. Chem. Eng. 2019, 7, 103219. [CrossRef]

20. Dantas, J.; Leal, E.; Mapossa, A.B.; Silva, A.S.; Costa, A.C.F.d.M. Synthesis, characterization and catalytic performance of mixed nanoferrites submitted to transesterification and esterification reaction using methyl and ethyl route for biodiesel production. Rev. Mater. 2016, 21, 1080-1093. [CrossRef]

21. Zhang, P.; Shi, M.; Liu, Y.; Fan, M.; Jiang, P.; Dong, Y. Sr doping magnetic CaO parcel ferrite improving catalytic activity on the synthesis of biodiesel by transesterification. Fuel 2016, 186, 787-791. [CrossRef]

22. Ashok, A.; Kennedy, L.J.; Vijaya, J.J. Structural, optical and magnetic properties of $\mathrm{Zn}_{1-\mathrm{x}} \mathrm{Mn}_{\mathrm{x}} \mathrm{Fe}_{2} \mathrm{O}_{4}(0 \leq \mathrm{x}$ $\leq$ 0.5) spinel nano particles for transesterification of used cooking oil. J. Alloys Compd. 2019, 780, 816-828. [CrossRef]

23. Ashok, A.; Kennedy, L.J. Magnetically Separable Zinc Ferrite Nanocatalyst for an Effective Biodiesel Production from Waste Cooking Oil. Catal. Lett. 2019, 149, 3525-3542. [CrossRef]

24. Salimi, Z.; Hosseini, S.A. Study and optimization of conditions of biodiesel production from edible oils using $\mathrm{ZnO} / \mathrm{BiFeO}_{3}$ nano magnetic catalyst. Fuel 2019, 239, 1204-1212. [CrossRef]

25. Sano, N.; Yamada, K.; Tsunauchi, S.; Tamon, H. A novel solid base catalyst for transesterification of triglycerides toward biodiesel production: Carbon nanohorn dispersed with calcium ferrite. Chem. Eng. J. 2017, 307, 135-142. [CrossRef]

26. Ashok, A.; Ratnaji, T.; John Kennedy, L.; Judith Vijaya, J.; Gnana Pragash, R. Magnetically recoverable $\mathrm{Mg}$ substituted zinc ferrite nanocatalyst for biodiesel production: Process optimization, kinetic and thermodynamic analysis. Renew. Energy 2020, 163, 480-494. [CrossRef]

27. El-Batal, A.I.; Farrag, A.A.; Elsayed, M.A.; El-Khawaga, A.M. Biodiesel production by aspergillus Niger lipase immobilized on barium ferrite magnetic nanoparticles. Bioengineering 2016, 3, 14. [CrossRef]

28. Pontes, J.R.M.; Leal, E.; Costa, A.C.F.M. Estudo da atividade catalítica do compósito cerâmico magnético $\gamma-\mathrm{Fe}_{2} \mathrm{O}_{3} / \mathrm{Ba}_{3} \mathrm{Co}_{2} \mathrm{Fe}_{24} \mathrm{O}_{41}$ para produção de biodiesel. Rev. Eletr. Mater. Process. 2020, 15, 43-49.

29. Ali, R.M.; Elkatory, M.R.; Hamad, H.A. Highly active and stable magnetically recyclable $\mathrm{CuFe}_{2} \mathrm{O}_{4}$ as a heterogenous catalyst for efficient conversion of waste frying oil to biodiesel. Fuel 2020, 268, 117297. [CrossRef]

30. Da Silva, A.L.; Farias, A.F.F.; Pontes, J.R.M.; Rodrigues, A.M.; Costa, A.C.F.d.M. Synthesis of the $\mathrm{ZnO}-\mathrm{Ni}_{0.5} \mathrm{Zn}_{0.5} \mathrm{Fe}_{2} \mathrm{O}_{4}-\mathrm{Fe}_{2} \mathrm{O}_{3}$ magnetic catalyst in pilot-scale by combustion reaction and its application on the biodiesel production process from oil residual. Arab. J. Chem. 2020. [CrossRef]

31. Costa, A.C.F.M.; Kiminamin, R.H.G.A. Dispositivo para a produção de manocompósitos cerâmicos em larga escala por reação de combustão e processo contínuo de produção de nanocompósitos. Rev. Propr. Ind. RPI 2012, BR 10 2012, 002181-3.

32. Jain, S.R.; Adiga, K.C.; Pai Verneker, V.R. A new approach to thermochemical calculations of condensed fuel-oxidizer mixtures. Combust. Flame 1981, 40, 71-79. [CrossRef]

33. Avila, P.R.T.; da Silva, E.P.; Rodrigues, A.M.; Aristizabal, K.; Pineda, F.; Coelho, R.S.; Garcia, J.L.; Soldera, F.; Walczak, M.; Pinto, H.C. On manufacturing multilayer-like nanostructures using misorientation gradients in PVD films. Sci. Rep. 2019, 9, 15898. [CrossRef] [PubMed]

34. Klug, H.P.; Alexander, L.E. X-ray Diffraction Procedures: For Polycrystalline and Amorphous Materials, 2nd ed.; Wiley: New York, NY, USA, 1974; ISBN 978-0-471-49369-3.

35. Rietveld, H.M. Line profiles of neutron powder-diffraction peaks for structure refinement. Acta Crystallogr. 1967, 22, 151-152. [CrossRef]

36. Pereira da Costa, F.; Rodrigues da Silva Morais, C.; Rodrigues, A.M. Sustainable glass-ceramic foams manufactured from waste glass bottles and bentonite. Ceram. Int. 2020, 46, 17957-17961. [CrossRef]

37. Costa, F.P.d.; Morais, C.R.d.S.; Pinto, H.C.; Rodrigues, A.M. Microstructure and physico-mechanical properties of $\mathrm{Al}_{2} \mathrm{O}_{3}$-doped sustainable glass-ceramic foams. Mater. Chem. Phys. 2020, 256, 123612. [CrossRef]

38. Fernandes, J.V.; Rodrigues, A.M.; Menezes, R.R.; Neves, G.d.A. Adsorption of Anionic Dye on the Acid-Functionalized Bentonite. Materials 2020, 13, 3600. [CrossRef] 
39. Olhero, S.M.; Soma, D.; Amaral, V.S.; Button, T.W.; Alves, F.J.; Ferreira, J.M.F. Co-precipitation of a Ni-Zn ferrite precursor powder: Effects of heat treatment conditions and deagglomeration on the structure and magnetic properties. J. Eur. Ceram. Soc. 2012, 32, 2469-2476. [CrossRef]

40. Hajalilou, A.; Hashim, M.; Mohamed Kamari, H. Structure and magnetic properties of $\mathrm{Ni}_{0.64} \mathrm{Zn}_{0.36} \mathrm{Fe}_{2} \mathrm{O}_{4}$ nanoparticles synthesized by high-energy milling and subsequent heat treatment. J. Mater. Sci. Mater. Electron. 2015, 26, 1709-1718. [CrossRef]

41. Mapossa, A.B.; Dantas, J.; Kiminami, R.H.G.A.; Silva, M.R.; Costa, A.C.F.M. Síntese do ferroespinélio $\mathrm{ZnFe}_{2} \mathrm{O}_{4}$ e avaliação do seu desempenho em reações de esterificação e transesterificação via rota metílica. Rev. Eletr. Mater. Process. 2015, 10, 137-143.

42. Li, J.; Ng, D.H.L.; Song, P.; Song, Y.; Kong, C. Bio-inspired synthesis and characterization of mesoporous $\mathrm{ZnFe}_{2} \mathrm{O}_{4}$ hollow fibers with enhancement of adsorption capacity for acid dye. J. Ind. Eng. Chem. 2015, 23, 290-298. [CrossRef]

43. Abdullah Dar, M.; Shah, J.; Siddiqui, W.A.; Kotnala, R.K. Study of structure and magnetic properties of Ni-Zn ferrite nano-particles synthesized via co-precipitation and reverse micro-emulsion technique. Appl. Nanosci. 2014, 4, 675-682. [CrossRef]

44. Salvador, V.L.R. Separação de Efeitos de Sobreposição de Espectros Obtidos por Wdxrf Usando o Método de Rietveld Vera Lucia Ribeiro Salvador; Instituto de Pesquisas Energéticas e Nucleares: São Paulo, Brazil, 2005.

45. Pauluk, S. Estudo da Estrutura Cristalina de Pigmentos de Zirconitas a Partir dos Sistemas $\mathrm{ZrSiO}_{4}-\mathrm{Co}_{3} \mathrm{O}_{4}$ e $\mathrm{ZrSiO}_{4}-\mathrm{Cr}_{2} \mathrm{O}_{3}$ Utilizando o Método de Rietveld; Universidade de Ponta Grossa: Ponta Grossa, Brazil, 2008.

46. ALOthman, Z. A Review: Fundamental Aspects of Silicate Mesoporous Materials. Materials 2012, 5, $2874-2902$. [CrossRef]

47. Dantas, J.; Silva, A.S.A.; Costa, A.C.F.M.; Freitas, N.L. Síntese, caracterização dos espinélios $\mathrm{NiFe}_{2} \mathrm{O}_{4}$ e $\mathrm{CoFe}_{2} \mathrm{O}_{4}$ e avaliação do desempenho na transesterificação e esterificação do óleo de algodão. Rev. Eletr. Mater. Process. 2012, 7, 174-179.

48. Silva, A.L.; Luna, C.B.B.; Chaves, A.C.; Neves, G.A. Avaliação de novos depósitos de argilas provenientes da região sul do Amapá visando aplicação na indústria cerâmica. Ceramica 2018, 64, 69-78. [CrossRef]

49. Da Silva, A.L.; Luna, C.B.B.; Chaves, A.C.; Neves, G.d.A. Caracterização tecnológica de novos depósitos de argilas da região sul do Amapá visando aplicações na indústria Cerâmica. Rev. Mater. 2017, 22. [CrossRef]

50. Michot, L.J.; Bihannic, I.; Thomas, F.; Lartiges, B.S.; Waldvogel, Y.; Caillet, C.; Thieme, J.; Funari, S.S.; Levitz, P. Coagulation of Na-montmorillonite by inorganic cations at neutral $\mathrm{pH}$. A combined transmission X-ray microscopy, small angle and wide angle X-ray scattering study. Langmuir 2013, 29, 3500-3510. [CrossRef]

51. Dumitrescu, A.M.; Samoila, P.M.; Nica, V.; Doroftei, F.; Iordan, A.R.; Palamaru, M.N. Study of the chelating/fuel agents influence on $\mathrm{NiFe}_{2} \mathrm{O}_{4}$ samples with potential catalytic properties. Powder Technol. 2013, 243, 9-17. [CrossRef]

52. Jandl, S.; Deslandes, J. Infrared spectra of HfS3. Phys. Rev. B 1955, 99, 1727-1735. [CrossRef]

53. Lazarević, Z.Z.; Jovalekić, C.; Milutinović, A.; Sekulić, D.; Slankamenac, M.; Romčević, M.; Romčević, N.Z. Study of nife ${ }_{2} \mathrm{O}_{4}$ and $\mathrm{ZnFe}_{2} \mathrm{O}_{4}$ spinel ferrites prepared by soft mechanochemical synthesis. Ferroelectrics 2013, 448, 1-11. [CrossRef]

54. Sivakumar, P.; Ramesh, R.; Ramanand, A.; Ponnusamy, S.; Muthamizhchelvan, C. Preparation and properties of nickel ferrite $\left(\mathrm{NiFe}_{2} \mathrm{O}_{4}\right)$ nanoparticles via sol-gel auto-combustion method. Mater. Res. Bull. 2011, 46, 2204-2207. [CrossRef]

55. Vieira, D.A.; Diniz, V.C.S.; Cornejo, D.R.; de Melo Costa, A.C.F.; Kiminami, R.H.G.A. Study of the Reproducibility of Ni-Zn Nanoferrite Obtained by Combustion Reaction. Mater. Sci. Forum 2014, 775-776, 415-420. [CrossRef]

56. Lima, D.S.; Perez-Lopez, O.W. Conversão catalítica do etanol sobre catalisadores suportados em ZSM-5. Ceramica 2018, 64, 1-9. [CrossRef]

57. Sawa, M.; Niwa, M.; Murakami, Y. Relationship between acid amount and framework aluminum content in mordenite. Zeolites 1990, 10, 532-538. [CrossRef]

58. Masiero, S.S.; Marcilio, N.R.; Perez-Lopez, O.W. Aromatization of methane over Mo-Fe/ZSM-5 catalysts. Catal. Lett. 2009, 131, 194-202. [CrossRef] 
59. Holanda, A. Biodiesel e Inclusão Social; Coordenação de Publicações: Brasília, Brazil, 2004; Volume 26.

60. Dantas, J.; Leal, E.; Mapossa, A.; Cornejo, D.; Costa, A. Magnetic nanocatalysts of $\mathrm{Ni}_{0.5} \mathrm{Zn}_{0.5} \mathrm{Fe}_{2} \mathrm{O}_{4}$ doped with $\mathrm{Cu}$ and performance evaluation in transesterification reaction for biodiesel production. Fuel 2017, 191, 463-471. [CrossRef]

Publisher's Note: MDPI stays neutral with regard to jurisdictional claims in published maps and institutional affiliations.

(C) 2020 by the authors. Licensee MDPI, Basel, Switzerland. This article is an open access article distributed under the terms and conditions of the Creative Commons Attribution (CC BY) license (http://creativecommons.org/licenses/by/4.0/). 